\title{
Veil of Light
}

\author{
Işı̆̆ın Örtüsü̈
}

\section{T. Mikail P. DUGGAN*}

\begin{abstract}
This article attempts to provide some explanation for the variety of sun - 'stars', shamsa in shabaka geometric designs by looking at some of the Koranic references and metaphysical works concerning Light and light, Sun and sun, Reality and phenomena. These designs became increasingly employed from the $\mathrm{XI}^{\text {th }}$ c. onwards over a wide variety of surfaces and media, and can be understood as representing the Lights-Suns of the Veil of Light(s) that separates the 'Face' of the Almighty from all else. The exposure to the Word in the Mushaf with the ayet being separated by a depiction of a shamsa, a little sun, with the Real Sun being the Light of the Absolute, the combination of the Word and the Light, rooted these sun-sunburst centred designs within Islam.
\end{abstract}

Keywords: Veil of Light, Sun-Sunbursts-Şemse-Shamsa-Rosettes, Geometric Pattern, Dark Light

Öz: Bu makale 'Nur' ve 1şık, 'Nur' ve güneş, Gerçeklik ve olguları bazı Kuran referanslarına ve metafizik çalışmaları inceleyerek güneşin 'yıldızlar' ve shabaka geometrik desenleri içindeki şems gibi çeşitli durumlarına açılama getirmeye çalışır. Bu desenler XI. Yüzyıldan itibaren medya ve yüzeylerde geniş bir yelpazede giderek kullanılır hale geldi ve Güneş'in Peçesi'nin Nur-Güneş'inin Allah'ın Yüz'ünü bütün başka şeylerden ayırdığı düşünülür. İslam'ın içinde köklü olan bu güneş- şems merkezli, Kelime ve Nur kombinasyonu, ayetle birlikte Mushaf'ta açığa çıkan kelime eş-şemse, küçük güneş, tasviri tarafından İlahi Nur'un Gerçek Güneş’iyle birlikte ayrılır.

Anahtar sözcükler: Işı̆̆ı̆ Gölgesi, Nur-Şems-Şemse-Shamsa-Rosettes, Geometrik Desen, Karanlık Işık

The 'Veil of Light' (Al-Ghazali 1998, 51), that Sun concealing the 'Face' of the Almighty as, "With good fortune you will see the Sun in the shadow" (Attar, 1978, 31-2) - Some XI ${ }^{\text {th }}$ to XIII ${ }^{\text {th }}$ c. references to the 'Sun/Light' of the Absolute and to that Light - of some probable importance in the designs employed in the arts, in particular the variety of sun and 'stars' shamsa in shabaka geometric designs representing the Veil of Light.

We are reminded of the lamp and of 'His light', that is of the Divine Light of the Almighty, which is described in the Sura Al-Nür, (Chapter Light) 24:35, and consequently of that beyond temporal being which causes the Divine Light, that is, the One, the Alone, the Existent, The Everlasting - al-Bāqī, the Almighty:

"God is the light of the heavens and the earth. His light may be compared to a niche that enshrines a lamp, the lamp within a crystal of star-like brilliance. It is lit from a blessed olive tree neither eastern nor western. Its very oil would almost shine forth, though no fire touched it. Light upon light; God guides to His light whom He will. God speaks in

\footnotetext{
* Lecturer, Akdeniz University, Mediterranean Civilisations Research Institute, Antalya, tmpduggan@yahoo.com
} 
metaphors to men. God has knowledge of all things".

And in the Sura Al-Qasas, The Story, 28:88 that: "Everything is perishing except His face", that is all that is, except for 'His Face', has only a relative and only a temporary existence. That which is permanent, in absolute terms, is only 'His face'; as distinct from the Veil, as from the relatively transitory nature of the universe, of the sun, the moon, the stars and the sky, of mountains, seas or the borrowed robe of human existence, time and all else.

While the Prophet Muhammad said: "His (Allah) is a veil of light. If He were to remove it, the glory of His countenance would ignite everything of creation as He looks upon it" (Sahīh Muslim (179). See also reference to the Light of the countenance of the Almighty in the prayer of the Prophet leaving Taif: "I take refuge in the light of Your Face that dispels the darkness and puts in order the affairs of this world and of the next world is set right, lest Your anger or Your displeasure descends upon me. I desire Your pleasure and satisfaction until You are pleased. There is no power and no might except by You"); "God has seventy veils of light and darkness; were He to lift them, the august glories of His face would burn up everyone whose eyesight perceived Him"(Cited in Al-Ghazali 1998, 44, and where the 70 or 70,000 veils of light and darkness are understood to represent a large, rather than a specific number), that which is Allah lies behind/within/beyond and is different and distinct from this 'veil of light', as the phrase, 'If He were to remove it,' makes explicit in this hadith, and, although the light issues from the Veil(s) of the Almighty, the light is not the Almighty, and, although this light has at times been understood as being 'the Countenance'(Holy Koran: Al-Baqarah, 2:52, "Repel not those who call upon their Lord at morn and evening, seeking His countenance"; Ar-Rūm, 30:38, "So give to the kinsman his due, and to the needy, and to the wayfarer. That is best for those who seek Allah's Countenance. And such are they who are successful”; Ar-Rūm, 30:39 “...but that which you give in charity, seeking Allah's Countenance, hath increase manifold"), or the 'Face of the Almighty', it is the Veil of Light, as Omar Khayyam (c. 1048-1126) described:

“There was a Veil past which I could not see:” (Fitzgerald, 1970, ruba’i No. 32).

That the Countenance-Face of the Almighty is both distinct from and separate from the veil is further recorded in the Holy Koran:

"And it was not (vouchsafed) to any mortal that Allah should speak to him unless (it be) by revelation or from behind a veil, or (that) $\mathrm{He}$ sendeth a messenger to reveal what He will by His leave. Lo! He is Exalted, Wise" (Holy Koran, Ash-Shūrā, 42:51).

And: "Everyone that is thereon will pass away; There remaineth but the Countenance of thy Lord of Might and Glory” (Holy Koran, Al-Wāqi'ah, 56:26-27).

As likewise the temporal consequences of exposure to the Countenance-Face of the Almighty (The Prophet on the Mi'rāj-Night Journey has been said by some to have passed beyond the veil, eg.by Nizami of Ganja (1140-1 to c. 1208-9) at the end of the XII ${ }^{\text {th }}$ c. in his Haft Paikar, 1924, l. 122-133:

"His distance of "two-bow lengths" at that time passed to "or nearer (then) from "he drew near"

Beyond his own existence did he step, so that his seeing God was possible. When thousands he had torn of veils of light, his eyes obtained the Light devoid of veil. 
The Object of his worship seen with truth, he washed his eyes from everything besides.

His eyes in no direction rested there whence salutation, left or right he heard.

Below, above, before, behind, left, right, were one direction and the six were gone.

"Direction's" unknown to "directionless": he left "direction" for "Directionless".

When the "Directionless" with fierceness flames, "direction" and the world both took to flight.

Until the eyes inveil "direction's" face, the heart's perturbed by anxious thought and care.

Nought of the Prophet was there save breath was left: there was no person left there, all was God.

When the eyes "direction" is concealed, "that which has no direction"is clearly seen.

How can "direction" compass sight of Him? How can it hold His encompassing?

Without "direction" when the Prophet saw the One, he heard words from no lips or mouth"), are also recorded:

"And when Moses came to our appointed tryst and his Lord had spoken unto him, he said: My Lord! Show me (Thy Self), that I may gaze upon Thee. He said: Thou wilt not see Me, but gaze upon the mountain! If it stands still in its place, then thou wilt see Me. And when his Lord revealed (His) glory to the mountain He sent it crashing down. And Moses fell down senseless" (Holy Koran, Al-A'rāf, 7:143). "And when We shook the Mount above them as it were a covering, and they supposed that it was going to fall upon them (and We said): Hold fast to that which We have given you, and remember that which is therein, that ye may ward off (evil)" (Holy Koran Al-A'rāf, 7:171). As, relatedly: "If We had caused this Qur'ān to descend upon a mountain, thou $(O$ Muhammad) verily hadst seen it humbled, rent asunder by the fear of Allah" (Holy Koran, Al-Hashr, 59:21).

It was from this understanding, that the first thing that was created from the darkness of nonexistence by the Almighty was light, (Eg., Bierman, 1998, 82; stemming from the hadith: "the first thing that God created was light.") and it was in consequence of this that Ibn Sina (9801037) in his Kitābu'l-Ishārāt identified the Aristotelian 'Aql, the Prime Reason, with the Light of Allah, with reference to Sura 24:35; as later in the XIII ${ }^{\text {th }}$ c. Jelal ad-Din Rumi would write, "Light is the First Cause, and every secondary cause its shadow" (Dīwān-i Shams-i Tabrīzī, 1. 525).

Abu Nasr, 'Abd Allah b. 'Ali al-Sarraj (d. 988) made reference to this light in the 'Book of Flashes' of the title and in the text of his Kitab al-luma' fi al-tasawwuf (He cites the comment by Yusuf b. al-Husayn on the Tradition, "Beware of the sagacity of the true believer, for he sees by the light of God" Nicholson, 1914, 63) and wrote in Chapter CXLVII:

"Concerning those who err in respect of illumination (al-anwār).

There are some who assert that their hearts are illuminated by divine 
light the light of gnosis and unification and majesty -- and this light they declare to be uncreated. They commit a grave error, since all the lights that can be perceived and known are created, whereas the light of God does not admit of description or definition and cannot be comprehended by human knowledge.

The correct meaning of the light in the heart is knowledge, derived from God, of the criterion (furqān), which the commentators on Kor. 8, 23 interpret as "a light put in the heart in order that thereby truth may be distinguished from falsehood" (Nicholson, 1914, 117-118). For Abu Nasr's view concerning the belief that the spirit is part of the essential light of God, and that the spirit was made from light, were manifestly erroneous doctrines and were the result of forbidden speculation (Kor. 17:87), see, Nicholson, 1914, CLII, 120-121; also see, Al-An'ām 6:122).

Abu Hamid al-Ghazāli (1058-1111) wrote in the third chapter of his Miskhāt al-Anwār (The Niche of Lights):

"Concerning the meaning of the Prophet's words: "God has seventy veils of light and darkness; were He to lift them, the august glories of His face would burn up everyone whose eyesight perceived Him"( Al-Ghazali, 1998, 44) ... "Therefore, they have turned their faces...to Him who originates the heavens, originates the farthest celestial bodies, and originates the one who commands moving the heavens. They have arrived at an existent thing that is incomparable with everything that their sight had perceived. Hence, the august glories of His face - the First, the Highest, burn up everything perceived by the sights and insights of the observers. Thus, they find Him too holy for and incompatible with all that we described earlier." (Al-Ghazali, 1998, 51); that is, all would be extinguished, all the hierarchies of the reflections of the First Light, if this Veil of Light should be lifted to expose the Face of the Almighty.

As likewise, Farid ud-Din Attar (c. 1120-1220) wrote:

"If the veil which hides the mysteries from our eyes should fall, nothing would be left in the world. All visible forms would be reduced to nothing" (Attar, 1978, 64).

As likewise later Mevlana Jelal ad-Din Rumi (1207-73) related:

"If the Sun (Allah), by whom this world is illuminated, should approach a little (nearer), all will be burned" (See Mathnavi, Bk. 1, 141, the "Naked Sun", that is the Tremendous, the Face of the Almighty that extinguishes-destroys all that pass beyond the Veil, such through analogy is termed fanā, annihilation, to be burnt, the yandım of the expression: hamdım, piştim, yandım/unripe, cooked, burnt.).

The spiritual aspect of light, in this case represented by the light of the shadow-play, had been earlier mentioned by Omar Khayyam (c. 1048-1126), with the "Master of the Show" being the term employed in this ruba'i in Mehdi Aminrazavi's 2007 translation, to describe the Almighty:

"We are no other than a moving row,

Of Magic Shadow-shapes that come and go,

Round with the Sun-illuminated Lantern held,

In Midnight by the Master of the Show" (Aminrazavi, 2007, 147),

translated by Fitzgerald as: 
"For in and out, above, about, below

'Tis nothing but a Magic Shadow-show,

Play'd in a Box whose Candle is the Sun,

Round which we Phantom Figures come and go" (Fitzgerald, 1970, ruba'i, No. 46).

With the distinction clearly drawn by Omar Khayyam in this ruba'i between the Sunilluminated Lantern and the Master of the Show (Allah), that is, the Veil of Light and that which lies behind this veil; and also distinguishing between the sun, of the afilin, of those that set, as also of the name of the Koran Sura Al-'Asr (Chapter 103, The Declining Day), with that true Sun which does not set; as also the relative darkness of this temporal world, at night lit up at times by the moon of reflected sunlight, in comparison with the imaginal world (For the Imaginal World as described by Ibn 'Arabi see, Burckhardt, 1989, 12-16), that world of light without shadows and of the worlds' lying beyond the imaginal world, the light upon light of the Angels and the Veil, and seems through the use of the word "midnight" to describe the darkness of the temporal setting lit by the temporal sun.

His contemporary Abu Hamid al-Ghazāli (1058-1111) wrote extensively in his Miskhāt alAnwār (The Niche of Lights) composed towards the end of his life (Al Ghazali, 1998, XVII) upon light and colour in worldly-temporal terms as being something of a reflection - a similitude of the non-temporal world of dominion, and also upon the source of Light itself, of which we have in the temporal world a pale reflection in the light of the sun and stars and a paler reflection still of the light of the sun in the moonlight, the Light being the Veil of Light(s) concealing the Face of the Almighty,

"In other words, from God the secondary causes of existent things descend into the visible world, while the visible world is one of the effects of the world of dominion. The visible world comes forth from the world of dominion just as the shadow comes forth from the thing that throws it, the fruit comes forth from the tree, and the effect comes forth from the secondary cause. The keys to knowledge of effects are found only in their secondary cause. Hence, the visible world is a similitude of the world of dominion - as will be mentioned in the clarification of the niche, the lamp, and the tree" (Al-Ghazali, 1998, 12, an astoundingly beautiful commentary of the Koran Sura, 24. 35, Al Nur, of the niche, the lamp, and the tree).

"...the light nearest the First Source is more worthy of the name "light" because it is highest in level. The way to perceive a similitude of this hierarchy in the visible world is to suppose that moonlight enters through a window of a house, falls upon a mirror attached to a wall, is reflected from the mirror to an opposite wall, and turns from that wall to the earth so as to illuminate it. You know that the light on the earth comes from that on the wall, the light on the wall from that in the mirror, the light on the mirror from that in the moon, and the light in the moon from the light in the sun, since light shines from the sun onto the moon. These four lights are ranked in levels such that some are higher and more perfect than others. Each one has a "known station" and a specific degree which it does not overstep" (Al Ghazali, 1998, 14).

"The, in the true sense, light is that through which, for which and by which things are unveiled and beyond which there is no light from which this light could be kindled and take replenishment. Rather it possesses 
light in itself, from itself, and for itself, not from another. Moreover you know that only the First Light has these qualities.

In addition, you know that the heavens and earth are filled with light from the two levels of light: that is, the light ascribed to eyesight, that (light) is the stars, the sun and the moon that we see in the heavens, and their rays that are deployed over everything on the earth that we see. Through (this light) the diverse colours become manifest, especially in springtime. This light is also deployed over every situation of the animals, minerals, and all types of existent things. Were it not for these rays, colours would have no manifestation-or, rather, no existence; and all shapes and measures that become manifest to the senses are perceived by the function of colours. The perception of colours is inconceivable without these rays.

As for the suprasensory, rational lights, the higher world is filled with them; they are the substances of the angels. The lower world is also filled with them; they are animal and human life. Through the low, human light, the proper order of the world of lowness becomes manifest, just as through the angelic light the proper order of the world of highness becomes manifest. This is what God means by His words: "He configured you from the earth, and has given you to live therein" (Koran Sura, 11:61, Hūd). (Al Ghazali, 1998, 19. The citation given is from Holy Koran, 11:61, at Hūd, which reads, 'And unto (the tribe of) Thamud (We sent) their brother Salih. He said: O my people! Serve Allah, Ye have no other Allah save Him. He brought you forth from the earth and hath made you husband it. So ask forgiveness of Him and turn unto Him repentant. Lo! my Lord is Nigh, Responsive').

"One does not point to the light of the sun but, rather, to the sun. In the obvious sense of this example, everything in existence is related to God just as light is related to the sun" (Al Ghazali, 1998, 20).

"Know that you can come to know the meaning of the fact that God is the light of the heavens and the earth (Holy Koran, Sura 24:35, 'God is the light of the heavens and the earth.') in relation to manifest, visual light. For example, when you see the lights and greenness of springtime in the brightness of the day, you do not doubt that you see colours. But you may suppose that you do not see anything along with colours, since you say, "I see nothing with greenness along with greenness." A group of people have insisted on this, since they suppose that light has no meaning and there is nothing along with colours except colours. Hence they deny the existence of light, even though it is the most manifest of things. How could it (light) not be? For through it things become manifest. It is light which is seen in itself and through which other things are seen, as was said earlier. Jelal ad-Din Rumi provides an extended commentary upon these same lines:

"How wilt thou see red and green and russet, unless before (seeing) these three (colours) thou see the light.

Inasmuch as at night those colours were hidden, thou sawest that thy vision of the colour was (derived) from the light.

There is no vision of colour without the external light: even so it is with the colour of inward phantasy.

This outward (light) is derived from the sun and from Suhá (a star), while the inward (light) is from the reflexion of the beams of (Divine) Glory. 
The light which gives light to the eye is in truth the light of the heart: the light of the eye is produced by the light of hearts.

Again, the light which gives light to the heart is the Light of God, which is pure and separate from the light of intellect and sense.

At night there was no light: thou didst not see the colour; then it (the light) was made manifest by the opposite of light (darkness).

(First) comes the seeing of light, then the seeing of colour; and this thou knowest immediately by the opposite of light (darkness).

God created pain and sorrow for the purpose that happiness might be made manifest by means of this opposite.

Hidden things, then, are manifested by means of their opposite; since God has no opposite, He is hidden;

For the sight fell (first) on the light, then on the colour: opposite is made manifest by opposite, like Greeks and Ethiopians.

Therefore thou knewest light by its opposite: opposite reveals opposite in (the process of) coming forth.

The Light of God hath no opposite in (all) existence, that by means of that opposite it should be possible to make Him manifest:

Necessarily (therefore) our eyes do not perceive Him, though He perceives (us): see this (fact) from (the case of) Moses and the mountain (Sinai)", Rumi 1982, I, 1121-1135).

When the sun sets, when lamps are put away, and when shadows fall, the deniers perceive a self-evident distinction between the locus of the shadow and the place of brightness. Hence, they confess that light is a meaning beyond colours that is perceived beyond colours. It is as if the intensity of light's disclosure prevents it from being perceived and the intensity of its manifestation keeps it hidden. Manifestation may be the cause of hiddenness. When a thing passes its own limit, it reverts to its opposite” (Al Ghazali, 1998, 22).

"Now that you have recognised this, you should know that just as everything becomes manifest to eyesight through outward light, so also everything becomes manifest to inward insight through God. God is with everything and not separate from it. Then He makes everything manifest. In the same way, light is with all things, and through it they became manifest. But here a difference remains. It is conceivable that outward light may disappear through the setting of the sun. It becomes veiled so that shadows appear. As for the divine light through which everything becomes manifest, its disappearance is inconceivable. Or, rather, that it is impossible for it to change, so it remains perpetually with the things" (Al Ghazali, 1998, 23).

"The visible world is a ladder to the world of dominion, and travelling on the straight path (as in 1:6-7, 'show us the straight (or right) path, the path of those whom Thou hast favoured;') consists of climbing this ladder...If there were no relationship and connection between the two worlds, climbing from one world to the other would be inconceivable. Hence the divine mercy made the visible world parallel to the world of dominion, there is nothing in this world that is not a similitude of something in the world of domination" (Al Ghazali, 1998, 27. It may be that it is this matter of the nature of reflections, that means that for some Shii'ites the pilgrimage is legally voided by looking at oneself in a mirror during the course of it, see, Peters, 1994, 119).

"There are in the world of dominion noble and high luminous substances called "angels." Lights effuse from these angels upon human spirits, and because of these lights these angels may be called "lords"- that is why God is "Lord of the lords" (The Divine Names are described as lords by Ibn 'Arabi, eg. Schimmel, 1978, 270; but Al Ghazali's use of the term 'lords - 
arbāban' to identify and describe these gradations of light-angels in this work, within the perspective of the Holy Koran, 'Imrān 3:80 "And he commanded you not that ye should take the angels and the prophets for lords. Would he command you to disbelieve after ye had surrendered (to Allah)?”, is noteworthy.). These angels have diverse levels in their luminosity. Hence, it is appropriate for their similitude in the visible world to be the sun, the moon and the stars" (Al Ghazali, 1998, 27).

This being an expansion of his description of light in his earlier treatise on The Ninety-Nine Beautiful Names of God, al-Maqsad al-asnā fi sharh asmā' Allah al-husnāa:

"Were it conceivable that a person see only the sun and its light spreading over the horizon, it would be right for him to say: I see only the sun, for the light radiating from it is part of the whole and not extrinsic to it. So everything in existence is a light from the lights of the eternal power, and a trace from its traces. And as the sun is the source of light radiating to every illuminated thing, so in a similar fashion the meaning which words fall short of expressingthough it were necessarily expressed as 'the eternal power' -is the source of existence radiating to every existing thing. Yet there is nothing in existence but God - great and glorious - so it is possible for a knower to say: 'I know only God'” (Al Ghazali, 1992, 46).

And in the same work, his description of the Divine Name, Al-Nūr:

"Al-Nür - Light - is the visible one by whom everything is made visible, for what is visible in itself and makes other things visible is called 'light'. In the measure that existence is opposed to non-existence, what is visible cannot but be linked to existence, for no darkness is darker than non-existence. What is free from the darkness of non-existence, and even from the possibility of non-existence, who draws everything from the darkness of non-existence to the manifestation of existence, is worthy of being named light. Existence is a light streaming to all things from the light of His essence, for He is the light of the heavens and the earth (Citing the Holy Koran, AnNūr, 24:35). And as there is not an atom of the light of the sun which illuminates it, so there is not a single atom from the existents of the heavens and the earth and what lies between them which does not lead one by the very possibility of its existence to the necessary existence who brings them into being" (Al Ghazali, 1992, 145).

His brother Ahmad al-Ghazāli (d. 1126) wrote in his Sawānih:

"The being of the mote in the air is perceptible and its inaccessibility is obvious, but these two depend on sunshine.

You are the sun and we are the motes.

How can we appear unless you show your face?

How long will you veil your face?

Rise from behind the mountain for one moment, so we can rise" (Ghazzalī, 1986, 22).

At the court of Sultan Salāh ad-Dīn Ayyūbi (1169-93), where one of the sultan's wives was named Shamsa, the mother of 'Uthmān and Ya'qūb (Cameron, Lyons, \& Jackson 1997, 135), a shadow-play performance was watched by both the Sultan and by al-Qadi al-Fadil, with the Sultan's Vizier explaining the meaning of the performance to the Sultan in these words:

"What I have seen carries with it a weighty lesson; I have seen kingdoms come and go, and when the curtain was rolled up, lo! The mover of all was only One" (Arnold, 1965, 15-16. This can also be read as addressing the matter of the illusion of reality and the Reality of the Absolute, concerning tawhīd, of which reflection in a subtle sense as from the possibilities comes the relative reality of this universe and world. The degree and nature of the illusion is 
likewise a subtle matter, its understanding, the difference between al-wahda al-mutlaqa of Ibn Sab'in (d. 1270) and Ibn 'Arabi's wahdat al-wujūd).

Al-Qadi al-Fadil's remark not only indicates that the shadow play in the XII ${ }^{\text {th }}$ century was regarded by some at least of the audience as carrying in its very form a religious meaning that is fundamental to Islam, the form of the shadow-play itself representing tawheed, Oneness or Unity, Holy Koran, Sura At-Tauhid, The Unity, 112, "Say: He is Allah, the One! Allah, the eternally besought of all! He begatteth not nor was begotten. And there is none comparable unto Him", with al-Qadi al-Fadil remarking to the Sultan that, "the mover of all" represented by the light from the light source of the shadow-play was "only One", implying that the light source of the shadow play was thus a similitude of the Light of the Veil of the Almighty, of which the sun of daylight remains but a distant pale reflection.

Shihāb ud-Dīn as-Suhrawardī (For the debate in emphasis between the philosophical and mystical interpretations of his work see: Suhrawardi, The Philosophy of Illumination, A New Critical Edition of the Text of Hikmat al-ishrāq, Trans. J. Walbridge \& H. Ziai, Brigham Young University Press, 1999, xvii-xxi.) (Suhrawardī Maqtūl) (His date of birth ranges from 1166, 1170, 1171, see Razavi 1997, 1, while Schimmel, 1978, 259, gives 1153, suggesting he was probably killed at some point in his twenties or thirties, b. 1170? executed in 1191 by order of Salāh ad-Dīn. A consequence it is suggested of his suspected Isma'ili associations-influence, see for example, Razavi, 1997, 15, in respect to his "seven bodies" and in his use of the word hayākll in the title of his book, hayākll al-Nür, 'The Shape of Light', and in respect to Salāh adDīn's engagements with the contemporary 'Philosopher Kings' as represented by the Fatimid Caliphs and by the leader of the Isma'ilis, with the proximity of Shihab al-Din Suhrawardi to Salāh ad-Dīn's son, Prince of Aleppo, and with the allegation that some of Suhrawardī 's followers addressed him as, Abū'l-Futūh Rasūl Allāh, 'Prophet of God' (Razavi, 1997, 4), which led to Salāh ad-Dīn's order for Suhrawardī's execution in the context of the temporally threatening onset of the Third Crusade of 1191and of on-going Isma'ili activity that had already included: in 1175 the first attempt on Salāh ad-Dīn's life outside Aleppo when 13 Assassins struck the leader of the jihad against the Crusaders. They were sent from the Assassin stronghold of Mashaf in the Nusairi Mountains of Syria west of Hama, held by the Assassins since 1140, by Rashid al-Din Sinan in a contract killing paid for by al-Salih of Aleppo. Khumartekin of Bu Qubais, amongst others, was killed defending Salāh ad-Dīn. Salāh ad-Dīn wrote to his nephew and Governor of Egypt, Farruk Shah Izzal-Din Da'ud b. Shahanshah b. Ayyub, to be on his guard sleeping and waking, by day and night, at rest or journeying: he should only employ men whose religious faith he knew or who were guaranteed by those who had reason to fear the consequences of treachery, for "the knives have been distributed and large sums of money shared out amongst the Assassins." ; and again in 1176 on the $22^{\text {nd }}$ May, in a second attempt on Salāh ad-Dīn's life at the siege of A'zaz, where he was stabbed but survived and the 3 Assassins were cut down. As a result Salāh ad-Dīn's tent was protected with a stockade, he would not talk to anybody whom he did not recognize, and when he rode out, if he saw anyone in his entourage he did not recognize he had them removed from his vicinity. Then on the $21^{\text {st }}$ of April, 1178, the Assassins killed the Abbasid Caliph al-Mustadi's Vizier, Adud al-Din and on the $31^{\text {st }}$ of August, Salāh ad-Dīn's brother, Taj al-Mulk Abu Sa'id b. Ayyub was assassinated in a contract killing by the Assassins on behalf of Gumushtegin and subsequently in 1192 Conrad of Montferrat, elected king of Jerusalem was struck down by the Assassins in Tyre on the $28^{\text {th }}$ of April. Salāh ad-Dīn's concerns about Shii' ite-Isma'ili influence over, or as a potential threat to his son, Malik Zāhir, were certainly reasonable. 
It is evident that the visual climate in Aleppo within which Shihāb ud-Dīn as-Suhrawardī moved, already resonated with the importance of the Light and the Veil, given the quantity and prominence in the use of these designs on works commissioned somewhat earlier under Sultan Nūr ad-Dīn (1147-74), who played an important part through his commissions in the early emphasis upon the type of shabaka - lattice and star-sun pattern in XII ${ }^{\text {th }}$ c. Syria. This serving not simply as a reminder of the ruler's own name, but representing the veil of light, although the origin of these patterns may well have been within the Caliphal centre at Bagdad associated with the then ruling Shii'ite Buyids, although not being necessarily Shii'ite in origin, and dating perhaps from around the start of the $\mathrm{XI}^{\text {th }}$ c.) identified the Absolute with the Quranic name $n \bar{u} r$ (light) (Seemingly combining the Veil with that which is Veiled, that which is veiled being the Absolute, rather than the veil itself being the Absolute, Ahmad Ghazzalī, Sawannih Inspirations from the World of Pure Spirits, The Oldest Persian Sufi Treatise on Love. Trans. N. Pourjavady, KPI, London, 1986, 4) and his main theories have been summarised by S. H. Nasr as:

\begin{abstract}
"The Essence of the First Absolute Light, God, gives constant illumination, whereby it is manifested and it brings all things into existence, giving life to them through its rays. Everything in the world is derived from the Light of His essence and all beauty and all perfection are the gift of His bounty, and to attain fully to this illumination is salvation" (Nasr, 1963, 69; cited in Schimmel, 1978, 261).
\end{abstract}

Suhrawardī Maqtūl thereby combining the Veil of Light with the essence of the Almighty, God being described as the Essence of the First Absolute Light, a conflation present neither earlier, in for example Omar Khayyam or Abu Hamid Al-Ghazali, nor later in Ibn 'Arabi's writing, and Suhrawardī says the Absolute is the Koranic Name Nūr (Ghazzalī, 1986, 4, while Ahmad Ghazzali associates the Absolute Reality with Love). -Light, thereby seemingly limiting the Absolute Reality. There may have been problems within an Islamic context with this conflation made by Shihāb ud-Dīn as-Suhrawardī in terms of its understanding, in part, from the fact that the radiant light was that of Iblis before his rebellion, the Angel sometimes named 'Azāza'îl (Holy Koran, Al-Baqarah, 2:34. Re, 'Azāza' ̄̄l, see Halm, 2001, 82, and for a possible indication of this thinking and of the use of the word 'az'azel, see Leviticus, 16, eg., Feinberg, 1958, 325, where it is said be related to the Arabic 'azala, to remove, but in the Syriac version it is pronounced 'azaza'il, and interpreted as a name for the archangel Michael, while in the apocryphal Book of I, Enoch 6:7; 9:6; 10:4-6, Azazel is portrayed as the leader of the fallen angels. Feinberg, 1958, 332, writes: "The reduplication of the consonants of the root in Hebrew and Arabic gives the force of repetition, so that while azal means removed, azalzal means removed by repetition of acts. Azalzel, or azazel, therefore, means one who removes by a series of acts. .. .' It properly denotes one that removes or separates; yet a remover in such sort that the removal is not effected by a single act or at one moment, but by a series of minor acts tending to and issuing in a complete removal", and if this was the understanding of the word then it may have had some influence upon the Iraqi Isma'ili gnostic views of the mid-IX ${ }^{\text {th }}$ c. as later. However, Abu Nasr Sarraj defines the term thus: "al-azal. This term is equivalent to alqidam. The terms azal and azaliyyat are applied to God only. Saying of an ancient Sufi, which some condemned on the ground that it involves the eternity of things (qidam al-ashya).", Nicholson, 1914, 96, as the Divine Name and the term al-azal, both mean that which has the status of existing without a beginning, that is, the pre-eternal. For remarks qualifying this, as matters of fact concerning early Isma'ili Gnosticism, rather than concerning the received perception within an environment antagonistic to this particular way of thinking, see Daftary, 
2007, 136-7), and, given the problematic conflation made by Suhrawardī, its understanding could in the eyes of some, seem to more resemble a continuation of Zoroastrianism, Dualism and its various offspring than Islam, but God knows best its merits.

Muhyid Din Ibn 'Arabi (1165-1240) wrote of the metaphysics of light, of sight and of insight (Reference is made to the importance of ibn Arabi's work by S. Ögel, 1994, 100-103, however the emphasis is upon the universalist cosmos in his drawings representing the metaphysics of the universe and of 'stars' and of the Turkish tent as a cosmic representation, Light and the Veil of Light was not itself the focus, and as these design types occur more than a century earlier and Syrian designer-architects were active in Seljuk territory during the first decades of the XIII ${ }^{\text {th }}$ c., and presumably familiar with these designs from the buildings commissioned under Nūr al-Din from the mid-XII ${ }^{\text {th }}$ c., his contribution would seem to have been made in the spread of the metaphysics of Light and Unity within the Seljuk realm early in the XIII ${ }^{\text {th }}$ century, rather than any influence at the design level):

"There are those who know that the perception (idrāk) of seen things is due to the combination of the light of sight with the light of the luminous body, be it sun or lamp or other object. This is how observable objects appear to us. If the luminous body is lost, nothing appears, and if the sight is lost, nothing of what can be perceived by the combination of sight and external light is illuminated" (Arabi, 2000, 49). As likewise, "The non-existent potentialities do not appear in existence except insofar as they are receptive to the all-powerful God, just as the light of sight is receptive to the light of the luminous body" (Shamash 2000, 50).

"His appearance in His light is so intense that it overpowers our perceptions, so that we call His manifestations a veil" (Arabi, 1989, 26).

And, in reference to the Dark Light of the Almighty, ibn 'Arabi related an encounter in h. 590/1194 (Addas, 1993, 132 fn.1). He writes of it:

"Can you see how dark this Light is? Spread out your hands in front of you, and you will not see them. So I spread out my hands, and I did not see them. Then He said to me: This is My Light; you do not see in It anything other than Itself'. (Arabi, 2000, 50, citing his Mashāhid al-Asrār, p. 39. One may continue with modern physics and the analogy of known matter and that which is invisible and termed dark matter, of which physicists comprehend much of the mass of the universe apparently consists, that is dark energy plus dark matter, forming in total, $95.1 \%$ of the content of the universe, but which is itself invisible to us as it does not interact with electromagnetic radiation; as also with the matter and light bending (gravitational lensing) and absorbing characteristics of 'black holes' in this universe, like the fact of gravity bending lightstarlight as it passes through the gravitational field of the Sun, first verified in 1919 during a total solar eclipse over Brazil.).

Reminding in a sense of Ibn 'Arabi's description of the Mohammadan Reality of the Prophet as, "the untarnished mirror of divine perfections" (Addas, 2000, 23) that, "When he appeared, he was like the sun in which all light is lost..." (Addas, 2000, 22).

It seems perhaps that this is how night and day (black and white) are equal for those who are of the Company of Light (sāhibu'n-nür), when in the darkness of night there is the Light of Revealing and behind/beyond/within this brilliant light there is at its innermost part, mirrored by the suwaid $\bar{a}$, the small black spot in the human heart, the Dark Light, within which nothing 
other than It exists but which Itself is not visible. It seems it was possibly this Reality which can be understood as being what Farid ud-Din "Attar was addressing in his words, "With good fortune you will see the Sun in the shadow." (Attar, 1978, 31-2), that is, the Light of the Truth within the shadows of the darkness of the temporal world, which has its source within the Light of the Veil, within the Dark Light before the Absolute (In former times the closest commonly experienced approximation to the experience of the Dark Light of the Absolute was experienced with a total eclipse of the sun. For his statement on passing the sidrat al-muntaha $\bar{a}$, 'I became nothing but light...' Addas, 1993, 156); as likewise, “Even though they are in nature's darkness, they are with a light (nür), illuminating the darkness, due to the existence of contemplation" (Shamash, 2000, 49).

The Sura Al-Qasas, The Story, 28:88 that states: "Everything is perishing except His face", is related as: "All things shall perish except Himself", by Ibn Arabi, and as, "when what has never been disappears, and what has never ceased to be remains" (Addas, 2000, 58, 79, citing Shaykh Ansārī d. 1089, via Ibn al-'Arīf) with, 'what has never ceased to be' being the Face of the Almighty and 'what has never been', being all that is other than this.

The attention devoted to the matter of this True 'Light' is reflected in the titles given to important works, by Abu Nasr 'Abd Allah b. 'Ali al-Sarraj in the $\mathrm{X}^{\text {th }} \mathrm{c}$. and which includes for example: Najm al-Dīn Dāya Razi (1177-1256) who entitled the seventeenth chapter of his Merșād al-'ebād men al-mabdāa' elā'l-ma'ād or The Path of God's Bondsmen: From Origin to Return, 'The Witnessing of Lights' (For the contemporary record of the witnessing of these lights, see for example, Shakoor, 2012, 37-68), while the hadith collection made from Bukhari and Muslim's collections by Raziuddin Șaghānī, al-Ḥasan ibn Muḥammad, (1181-1252) is entitled Mashāriq al-anwār, 'Rising points of the Lights'; and Fakhr al-dīn Ibrahīm 'Irāqī (12131289) wrote a major work, composed in Konya, entitled, Lama'āt (Divine Flashes), influenced by Ahmad al-Ghazāli's Sawānih, and which sees the world as a mirror reflecting the Divine Light, Names and Attributes.

Later Jelal ad-Din Rumi (1207-1273) was to relate:

"The proof of the sun is the Sun (Himself): if thou require the proof, do not advert thy face from Him!

If the shadow gives an indication of Him, the Sun (Himself) gives a spiritual light every moment.

The shadow, like chat in the night hours, brings sleep to thee: when the sun rises the moon is cloven asunder.

There is nothing in the world so wondrous strange as the sun, (but) the Sun of the spirit is everlasting: it hath no yesterday.

Although the external sun is unique, still it is possible to imagine one resembling it;

The spiritual Sun, which is beyond the aether, hath no peer in the mind or externally.

Where is room in the imagination for His essence, that the like of Him should come into the imagination?

When news arrived of the face of Shamsu'ddin (the Sun of the Religion), the sun of the fourth heaven (the sun that lights this world) drew in its head (hid itself for shame)" (Rumi, 1982, Bk. 1, 116-123).

He also wrote: 
"His (the Almighty's) veil-making = (that is the creation of phenomena)" (Rumi, 1982, Bk. VI, 2883). In the sense not only that the creation of phenomena, the veil, both conceals its Maker, Al-Baatin (The Hidden), but also the veil indicates because of its existence the existence of the Maker of this veiling Az-Zaahir (The Manifest); but also that through the light from the Veil of Light the worlds and this world of phenomena become manifest as veils. As for example he clearly expresses when he writes of the world of archetypes and of their reflection/descent through the imaginal and into the temporal world:

" 'Tis light makes colour visible: at night

Red, green, and russet vanish from thy sight.

So to thee light by darkness is made known:

Since God hath none, He, seeing all, denies

Himself eternally to mortal eyes.

From the dark jungle as a tiger bright,

Form from the viewless Spirit leaps to light.

When waves of thought from Wisdom's Sea profound

Arose, they clad themselves in speech and sound.

The lovely forms a fleeting sparkle gave,

Then fell and mingled with the falling wave.

So perish all things fair, to readorn

The Beauteous One whence all fair things were born" (Trans. R. A.

Nicholson, in Arberry, 1969, 127).

And:

"If He did not exist, the heavens would not revolve, nor would they be the place of light and the station of the angels." (Rumi, 1982, VI, 2104;

Chittick, 1983).

And:

Love like a tower of light-

Inside the tower of light -

what a fire!" (Schimmel, 2001, 107).

As:

"Our death is our wedding with eternity.

What is the secret? "God is One."

The sunlight splits when entering the windows of the house.

This multiplicity exists in the cluster of grapes;

It is not in the juice made from the grapes.

For he who is living in the Light of God,

The death of the carnal soul is a blessing.

Regarding him, say neither bad nor good,

For he is gone beyond the good and the bad.

Fix your eyes on God and do not talk about what is invisible,

So that he may place another look in your eyes.

It is in the vision of the physical eyes

That no invisible or secret thing exists.

But when the eye is turned toward the Light of God 
What thing could remain hidden under such a Light?

Although all lights emanate from the Divine Light

Don't call all these lights "the Light of God" (A repetition for the same

reasons in the XIII ${ }^{\text {th }} \mathrm{c}$. as the warning made in the $\mathrm{X}^{\text {th }} \mathrm{c}$. by al-Sarraj

concerning the flashes-lights recorded in his Kitab al-luma' fi al-

tasawwuf given above);

It is the eternal light which is the Light of God,

The ephemeral light is an attribute of the body and the flesh.

...Oh God who gives the grace of vision!

The bird of vision is flying towards You with the wings of desire"

(Jalalud’din, Rumi, Mystic Odes (ghazaliyât), 833).

And:

'Twere better that the spirit which wears not true love as a garment

Had not been: its being is but shame.

Be drunken in love, for love is all that exists.

Dismiss cares and be utterly clear of heart,

Like the face of a mirror, without image or picture.

When it becomes clear of images, all images are contained in it.

No man's face is ashamed of that clear-faced one.

Wouldst thou have a clear mirror, behold thyself therein,

For it is not ashamed or afraid of telling the truth.

Since the steel face gained this purity by discrimination,

What needs the heart's face, which has no dust?

But betwixt the steel and the heart is this difference,

That one is the keeper of secrets, while the other is not" (Rumi, 1977,

XIII).

That is, when the heart becomes so polished it just reflects the Light, there is no room in that mirror for any form, but the secrets of the Almighty are secrets kept.

On the colours of the spiritual worlds and the shadows of this temporal world:

"When you see the leaves of your spirit yellow and black, how do you not know the anger of the King?

The King's Sun in the (Zodiacal) sign of reproach, makes faces black as pieces of roast meat.

Our souls are leaves for that Mercury (to write on): that white and black (writing) is our standard (criterion).

Again he writes a patent in red and green, that (our) spirits may be delivered from melancholy and despair.

Red and Green are Spring's cancellation (of winter); in regard (to their significance) they are like the (coloured) lines of the rainbow" (Rumi, 1982, Bk. II, l. 1596-1600).

"When you make a veil out of yellow glass, you will see the sun's light as yellow.

Break those blue and yellow glasses so that you may discern the man from the dust” (Mathnawi, Bk. 1, 3958-9). 
"You are your own shadow - become annihilated in the rays of the Sun! How long will you look at your shadow? Look also at His Light!" (Chittick, 1983, Dīwān-i Shams-i Tabrīzī, l. 20395).

"Although the wall casts a long shadow, (yet at last) the shadow turns back again towards it" (Mathnawi, R. A. Nicholson, Bk. I, l. 214. For some further references to the matter of shadows, see Duggan, 2011, 83-92).

The ghazal No. XII in the earliest translation of Rumi's Dīwān-i Shams-i Tabrīzī into English by R. A. Nicholson in 1898 also speaks of this matter, but since it doesn't occur in the earliest surviving texts of the Dīwān-i Shams-i Tabrīzī, it's thought to be a subsequent interpolation (There are seven ghazals, Nos. IV, VIII, XII, XVII, XXXI, XXXIII, and XLIV in Rumi (1898) 1977, that are not in the earliest surviving manuscript copies of the Divan and so are thought by scholars not to be by Rumi, although one may feel these were later interpolations of own Rumi's verse into the Dīwān-i Shams-i Tabrīzīi, or were written by someone who had tasted of this same matter):
"Every form you see has its archetype in the placeless world (al-falak al- atlas, the imaginal world) (Shah, 2000, 153, as likewise, Coomaraswamy 2004, 77, as likewise, Jackson 2004, 271);
If the (temporal) form perished, no matter, since its' original is everlasting.
Every fair shape you have seen, every deep saying you have heard, Be not cast down that it perished; for that is not so" (Rumi, 1977, XII, 47).

In the XIV ${ }^{\text {th }}$ c. Ibn Qayyim al-Jawziyya in his, The Invocation of God, Al-Wābil al-Sayyib min al-Kalim al-Tayyib, wrote:

'The religion of God is Light. His Book is light. (This expression was used earlier, in the poem by the blind poet of Bagdad Alı ibn Abi Talib at the time of the Caliph al-Amin, in which the Koran is described as the 'Book of Light', recorded in the $\mathrm{X}^{\text {th }}$ c. by Al-Mas' $\bar{u} d \overline{1}$, Masudi, 1989, 146. Even in purely visual terms 'His Book,' - 'the Book of Light,' is punctuated by the light reflected from the gold of the sunbursts-semse separating each ayet.) His messenger is Light (For example: Holy Koran, Al-Ahāzb, 33:45-46, "O Prophet! Lo! We have sent thee as a witness and a bringer of good news and a warner. And as a summoner unto Allah by His permission, and as a lamp that giveth light”, a shining lamp, sirāj munīr; as with, Al-An'ām, Cattle 6:122, "Can the dead man whom We raised to life, and given a light to walk with among men, be compared to him who is in darkness from which he will never emerge? Thus do their deeds seem fair to the unbelievers". Al-Hallaj in his Kitāb at-tawāsin describes the Prophet as being a part of God's light, as earlier Sahl at-Tustarī c. 900 had written, "When He wanted to create Muhammad He showed a light from His light which illuminated the whole kingdom", that is the Prophet was created from light, quoted, Schimmel, 1978, 215; as later in Nizami's Haft Paikar, 1. 44-45, "And then that through him (The Prophet) brightest day was shade-but shade, what means it with the sun conjoined?"). The abode which he has prepared for His friends glows with light. God is the light of the heavens and earth (Citing the Holy Koran, An-Nür, 24:35); one of His names is Light. And by the light of His face is darkness dispelled' (Ibn Qayyim, al-Jawziyya, 2004, 61-2).

\section{The Visual Representation of the Veil of Lights}

The visual depiction of what can be understood as being a representation of the Veil of Lights of the Almighty within the world of Islam unsurprisingly first occurs in the recording in script of 
the text of the Holy Koran, in the repeated sunbursts-şemse-shamsa or 'little suns'- rosette devices, often in gold or silver or of yellow paint, employed to mark the divisions in the text between the individual ayet.

These sunbursts were certainly employed from the late VIII ${ }^{\text {th }}-\mathrm{IX}^{\text {th }}$ c. onwards, if not earlier (Given the present confusion over the dating of early Koran pages, the date of the earliest use of a shamsa-sunburst divider is presently unclear. The Koran which the Caliph Osman is reported to have been reading at the time of his murder in h. 23/644 A.D., today in the T.S.M. Inv. No. H.S. 32 (Hırka-i Saadet Dairesi) Istanbul, has shamsa-sunburst ayet dividers drawn in ink often with 3 red dots around the centre). (Fig. 1). In consequence,

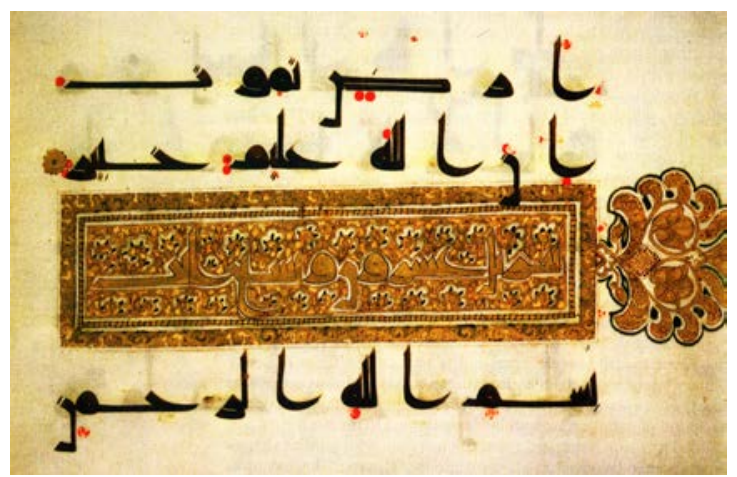

Fig. 1. Koran page Sura 31.34-32.1 (from Blair 2006, Fig. 4.4). the illuminated parchment Koran folio, or the later paper Koran page, presents the eye with the measured combination of both The Word and The Light, the flashes of light marking the end of each ayet, largely a feature of those mushaf which were made for recitation and display(A distinct type of Early Koran in Wheelan's typology, Type 1 , see, Blair, 2006, 111). In the case of the $\mathrm{IX}^{\text {th }}-\mathrm{X}^{\text {th }}$ c. Blue Koran, silver rosettes (formerly reflecting white, like stars, but now oxidized, reconstruction Fig. 2) to indicate the divisions between the individual ayet written in gold, and also employed in a gold circle to mark each group of twenty ayet set against the void of blue. These sunbursts-şemse-shamsa-rosette devices were also at times employed to add emphasis to a particular ayet (Eg. Holy Koran, lisrā, 17:9, "Lo! this Qur'an guideth unto that which is straightest, and giveth tidings unto the believers who do good works that theirs will be a great reward.", and Holy Koran, l-isrā, 17:82, "And We reveal of the Qur'an that which is a healing and a mercy for believers though it increase the evil-doers in naught save ruin").

Given the importance of the Holy text and of its appearance it seems reasonable to suggests that its visual appearance had significant consequences extending far beyond the illuminated page itself, and it is entirely unsurprising that in a poem by the blind poet of Bagdad known as Ali ibn Abi Talib written during the civil war between al-Amin and al-Ma'mun (810-14), the Holy Koran was described as the 'Book of Light', (Recorded in the $\mathrm{X}^{\text {th }}$ c. by Al-Mas'ūdī, Masudi 1989, 146:

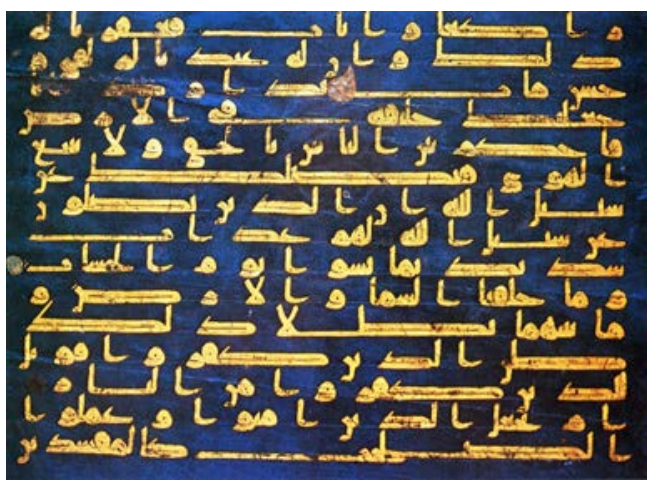

Fig. 2. Blue Koran page (from Burckhardt 1976, Pl. 23).
"Observe how a tyrant and a seducer (Amin and his Vizier Fadl ibn al-Rabi’)

Are conspiring together

To rend the Book of Light!

If it were not for the whims of fortune, What would these two ever have amounted to?

But destiny lifts up mountains

Upon which stand the base and the lowly

Men she raises up from nothing"), 


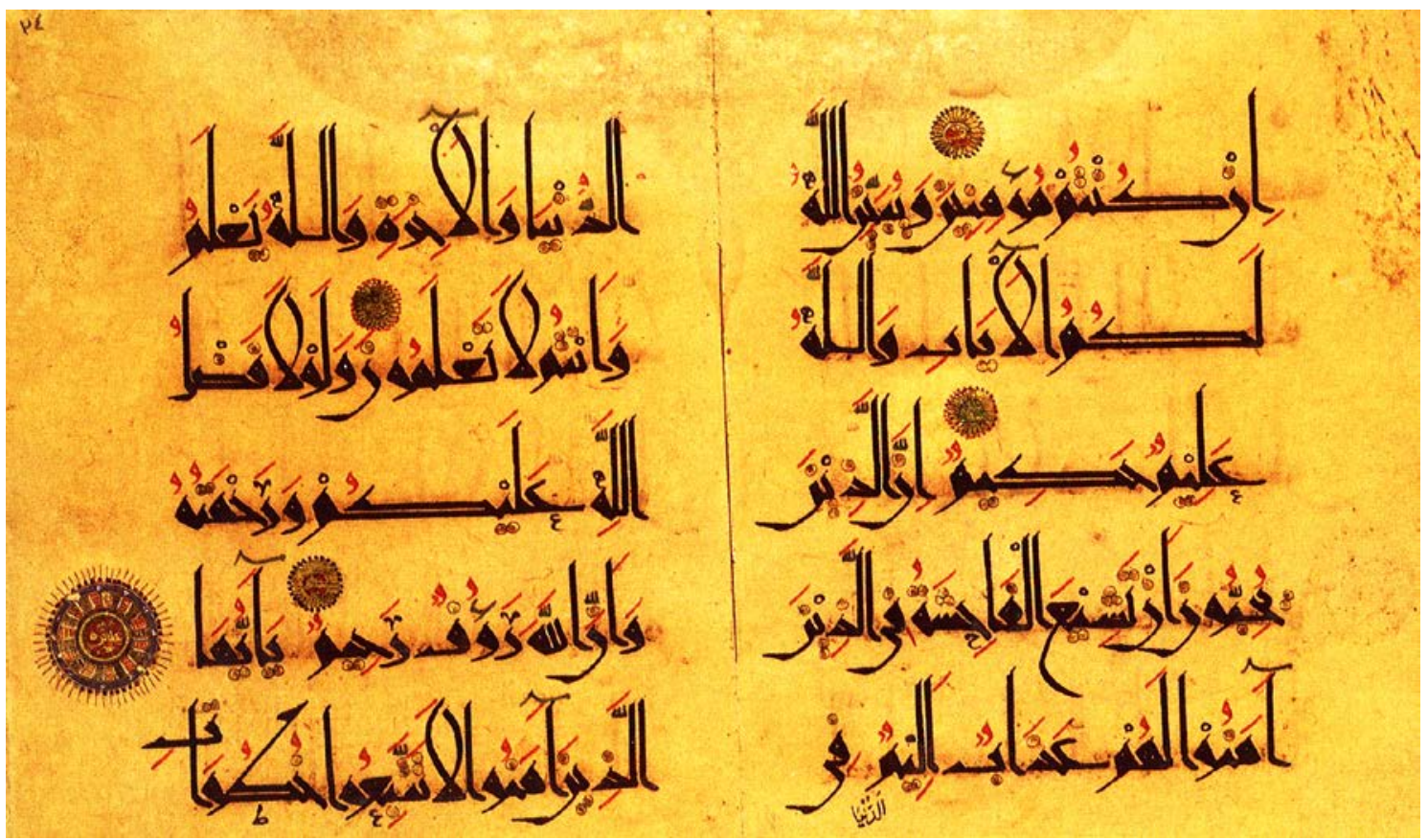

Fig. 3. $\mathrm{XI}^{\text {th }}-\mathrm{XII}^{\text {th }}$ c. Koran Section with shamsa (from Pancaroğlu, 2005, 82, Fig 36)

as it is such, in terms of both its content, it being described by the Almighty as such: "O mankind! Now hath a proof from your Lord come unto you, and We have sent down unto you a clear light” (Holy Koran, An-Nisâ, 4:174), and, from its visual appearance, with the pages of a mushaf carrying more than six-thousand depictions of little suns-sunbursts-shamsa (In some cases approximately 6,200 times if the Bism Allāh al-Rahmān al-Rahìm at the start of a sura was regarded as and counted as an ayet and so its end is marked with a shamsa-şemse, otherwise the shamsa-şemse is depicted approximately 6,100 times).

It may have been in part from the physical appearance of these pages recording the Word, marked by these sunbursts of light (Fig. 3), in addition to the light of The Word, of the Light itself, that works were given titles such as: Kitab al-luma', the Book of Flashes; Manārāt al-sā'erin elām'llāh wa maqāmāt al-țā'erīn be 'llāh, Light Towers for Those Voyaging to God and the Stations of Those Plying with God, and, Lama' $\bar{a} t$, Divine Flashes.

This paper suggests that the illuminated pages of the Holy Koran were understood as being a representation of the Veil(s) of Light(s) - with the measure and proportion of the calligraphic script of the Word based upon the width of the cut kalem nib, separated by the flashing sunbursts of the light, and, as with the Abbasid introduction of the mosque tower-minaret to

clearly mark and to distinguish the sole Abbasid congregational mosque in a city between 772 and 825 (see Bloom, 2013, 73, 96-111), with the lighting devices that were attached to it and with its sunlight reflecting surfaces (For the importance of light from the minaret by night and day, from oil lamps and from reflected light respectively, see Duggan, 2013), the emphasis upon light as a symbol was clearly articulated in the Abbasid urban environment by the $\mathrm{IX}^{\text {th }}-\mathrm{XI}^{\text {th }} \mathrm{c}$. across the territory of the Abbasid Caliphate, which included the production at Basra of lustre painted pottery and the spread through exports of this lustre painted pottery from the IX $^{\text {th }}$ c. to the late $X^{\text {th }}$ c. (Watson, 2004, 38), with noted influence also in some designs employed with those of manuscript illuminations (Watson, 2004, 183, and Cat. Nos. E4, E5, E11), then lustre production moved to Fatimid Egypt from the late $\mathrm{X}^{\text {th }}$ to the late XII ${ }^{\text {th }}$ c. and then to Syria from 
the mid-XII ${ }^{\text {th }}$ c. to 1258 and within Seljuk territory at Kashan from the late XII ${ }^{\text {th }}$ until the mid$\mathrm{XIV}^{\text {th }}$ c. (Watson, 2004, 40); and the related technique in its effect, of applying gold leaf to tilework, as on the revetments of hexagonal turquoise-green tiles as in the Karatay Medrese, Konya of 1251, together with the production of lustre painted 8 pointed sunburst tiles as at the palaces of Kubadabat and Aspendos under Seljuk Sultans in the XIII ${ }^{\text {th }}$ century.

This emphasis upon Light-light was repeated and echoed in the development of, and through the first use and the increasing employment during the period from the $\mathrm{XI}^{\text {th }} \mathrm{c}$. onwards, of shabaka-(girih) geometric designs (Y. Tabbaa, writes of this form of surface patterning: "Combining the purity and austerity of geometric principles with the celestial allusions of star patterns, geometric ornament reflected the ordered universe, whose atomistic and occasionalistic structure was created and sustained by divine intervention, and stimulated passion for the divine creator" Tabbaa, 2001, 101, although it seems this form of surface patterning may be more related to the depiction of the Veil of Light as a design, than necessarily to be alluding to celestial matters, or as being as directly associated with the Sunni Asharite atomistic and occasionalistic structure of the universe as has been suggested by Y. Tabbaa as the reasons for its design. Likewise, if this type of design with sunbursts-stars is understood as being rooted in and mentally associated with the visual appearance of the pages of the Koran and as representing a form of the Veil of Lights, then some greater degree of precision can be brought to the essentialist view that this type of pattern represents "an extremely direct expression of the Divine Unity underlying the inexhaustible variety of the world... 'unity in multiplicity' (alwahdah fi 'l-kathrah), the same as 'multiplicity in unity' (al-kathrah fi 'l-wahdah).” Burckhardt, 1976, 63. In respect to the use of the term shabaka, a net, rather than girih, see Tabbaa, 2001, fn. 16, 183), in particular, those designs with representations of the sun and sunbursts/or 'stars' (The modern terminological distinction drawn between the sun-sunburst and a star of a design seems in many cases to be a quite arbitrary if now standard distinction. It is quite another matter however if what are described today as a 5, 6 or 8 pointed stars were formerly understood as being stars, or rather were understood as being types of, and reminders of the True Sun, the Light of Truth, that is, shamsa-şemse, a little sun, as for example the cut-tile 5 pointed figures at the centre of the lunettes over the windows on either side of the entrance to the türbe of the Sultan Keykavas hospital of 1219-20 at Sivas, their description as stars seems indeed to be very doubtful. G. Öney, refers to the Great Seljuk and Rum Seljuk 8 pointed palace tiles as 'stars tiles', Öney, 1987, 20-21, 48, even when they are painted in luster, as does R. Arık, 'Insan yüzlü güneş tasvir edilen ylldı çini. Lüster', Arık, 2000, 132, as likewise 85, 91, 99, 106, 154, 161; while Y. Tabbaa, 2001 mentions the 'celestial allusions of star patterns.', Tabbaa 2001, 101, associating these designs with stars rather than suns, as likewise the so called 'star' Uşak carpets etc. Having written an article on these 8-pointed palace tiles, where following the modern terminology they are described as ' 8 pointed star tiles,' Duggan, 2006, passim, I believe I have swallowed a 6 legged spider, as it seems this form was almost certainly in the XII ${ }^{\text {th }}$ and XIII ${ }^{\text {th }}$ centuries understood as representing-reminding of the sun, and the light of the sun, and thereby of The Sun and The Light, and so was understood to be a shamsa, not a najmah, a star. In modern astronomy the earth orbits the sun, which in scientific terms is classified as a G2V star: a main-sequence dwarf star of moderate temperature, classified with other stars in the universe, if being a great deal closer to the earth. However, that the brightness of a star in the heart put into darkness the suns in the heavens is recorded when, for example Jelal ad-Din Rumi describes, "Suddenly in my bosom, a star shone clear and bright; All the suns of heaven Vanished in that star's light."), of "rosettes", shamsa - little suns, of angels in the form of lights - sunbursts, "Each one has a "known station" and a specific degree which it does not 


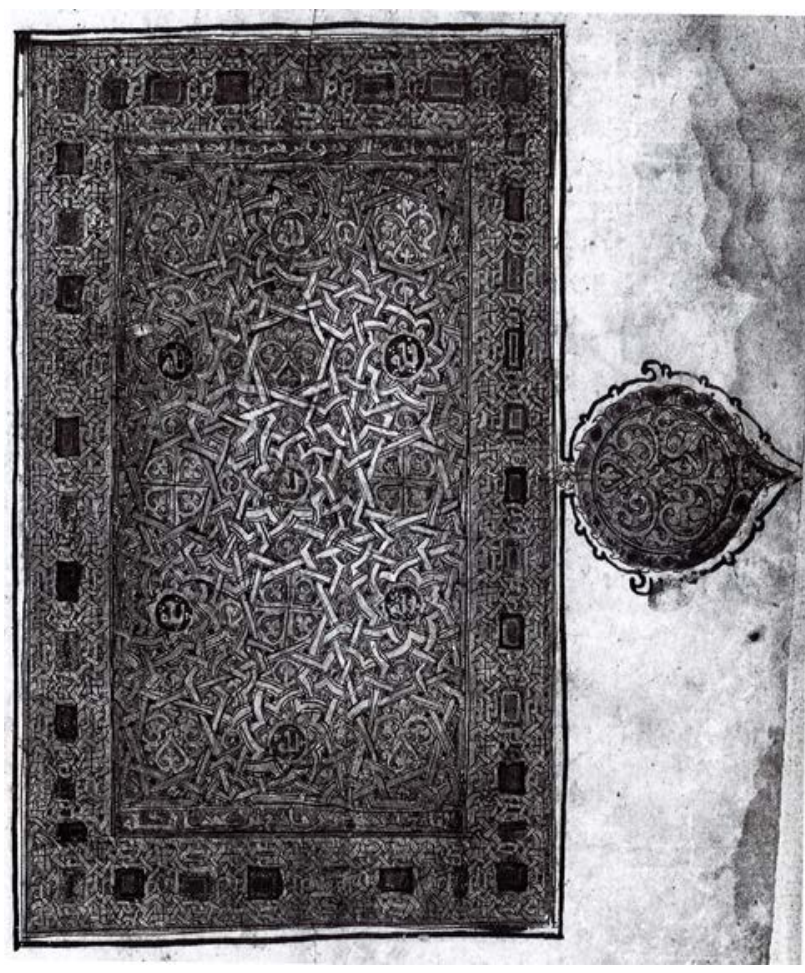

Fig. 4. Koran frontispiece 1036,

(from Tabbaa, 2001, Fig. 16)

overstep." (Al Ghazali, 1998, 14), depicted within the geometrically defined spaces between the interlace of the lattice, designs that can be understood as representing not just a geometric pattern, but of patterns which were deliberately designed to recall this Veil of Lights, providing visual remembrance, Dhikr for the eye and heart and mind of the aware, for the awake.

The articulation of these sunburst'star'-shamsa designs on works produced from the $\mathrm{XI}^{\text {th }}$ c. onwards, reflecting, as is suggested above, the importance of the Veil of Light(s), formed a characteristic design type of this period and these designs were employed over a wide range of surfaces in a variety of materials, these serving visually as a reminder within this temporal world of the Veil(s) of Lights of the Almighty. It may have been the case that the change from the Koran written in Kufi on the page to that in the more legible cursive proportioned script 'of assimilated geometry' (Tabbaa, 2002, 47) drew further attention to these sunburst-textual markers, and so, in a sense through these references to the Holy and legitimising text, to add, through the use of these sunburst-'star' designs on the surfaces of a minbar, a mihrāb, a door, a portal or on domes, a visual reminder of the Light of the Absolute, of that light of a quite different nature, as also to carry an implicit reminder of the mushaf.

In consequence of the importance given to this understanding, of the Veil of Light before the Face of the Almighty, described by numerous influential figures throughout the XI ${ }^{\text {th }}$ to XIII ${ }^{\text {th }}$ centuries and stemming from the accounts of Light/light and of the Veil of Light recorded in both the Koran and hadith, and articulated in a sense throughout the built environment through the spread of tower minarets, and their lights marking the night and its sky of stars like moons and suns, it seems to be quite within the realm of the possible that the 'veil' or shabaka-net of decoration containing, and built around the sun-shamsa-rosette (frequently divided into 8 segments of a sunburst, a geometric form formed through the rotation of a superimposed square upon a square, and a reminder for example of the 8 points of the sajdah: forehead, nose, hands, knees and toes), or the sun and 'stars' within this framework of geometric patterns, becomes increasingly widespread in their employment over a variety of surfaces, serving as a reminder, like the shamsa-rosette in the mushaf, of the Light of the Almighty in this world.

It seems that these sun-shamsa-'star' patterns were first developed in association with the decoration of the mushaf during the first decades of the $\mathrm{XI}^{\text {th }} \mathrm{c}$. and had spread by the late $\mathrm{XI}^{\text {th }} \mathrm{c}$. onto architectural surfaces, with, in the eastern Islamic world the ornamental skin of hazār baf, "began to give way by the late eleventh century to a more advanced geometric style mainly characterised by the use of overlaid strap-work and complex star patterns.” (Tabbaa, 2002, 78); 
although it seems probable that the used of these designs spread more rapidly outward from Bagdad than the late $\mathrm{XI}^{\text {th }} \mathrm{c}$.

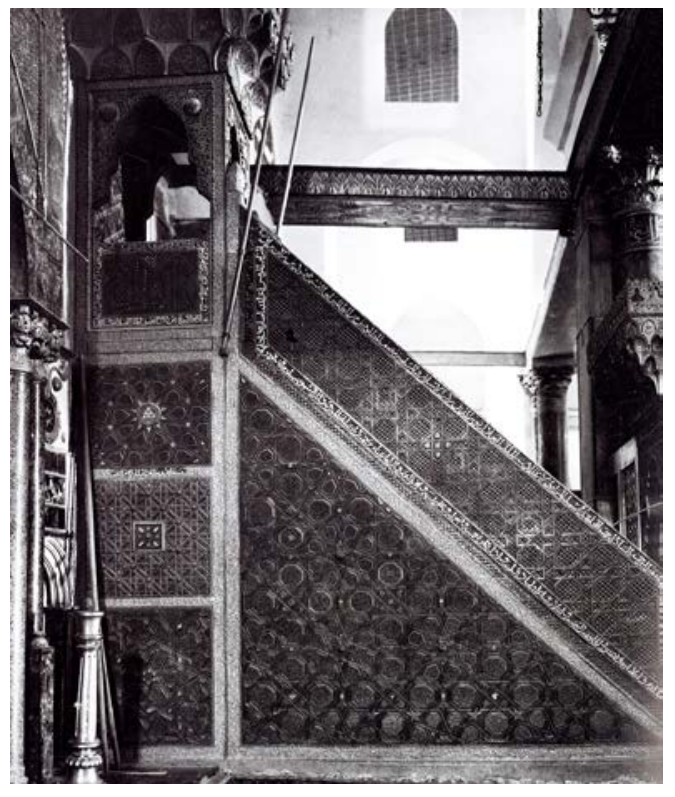

Fig. 5. Nur ed-Din minber 1168-74, sunbursts and 'stars' on the side of the al-Aqsa minbar (from Singer, 2008,70)

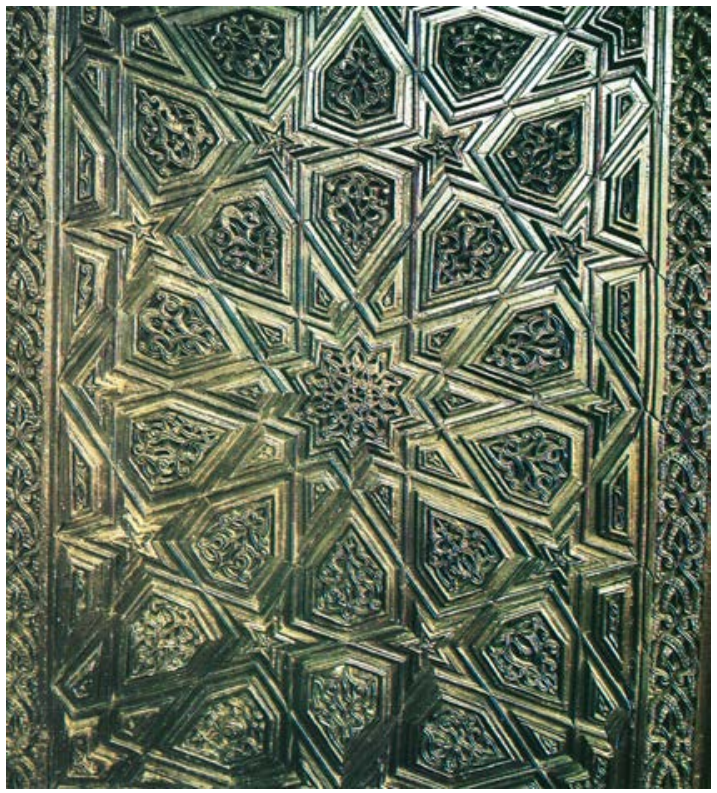

Fig. 6. Eşrefoğlu minber 1297-9, detail of sunburst on minbar (from Firat, 1996)

It is found employed in illuminated Koran manuscripts from the $\mathrm{XI}^{\text {th }}$ c. onwards (1036) (Fig. 4) (One of the earliest examples is the 1036 Koran frontispiece, B. Lib. Add. 7214, fol. 2b, with its geometric interlace and sunbursts with roundels in the centre of each sunburst. The sunburst'star' pattern does not occur in the interlace on the full page designs of ibn al-Bawwab's Koran of 1000-1001 Bagdad, today in the Chester Beatty Library, Dublin, No. 1431, except employed as a filling design between parts of the interlace, fol. 285a), as on the sides of minbars (Figs. 5 \& 6) (Eg. On the sides of the wooden minbar of the Alaeddin Mosque in Konya of 1154; as on the sides of the wooden minbar of the mosque al-Nūrī in Hama of 1163; as on the 1169 minbar of Nūr al-Dīn, Jerusalem (as likewise on its reconstruction completed in 2006 where sunbursts and shamsa-'stars' form a primary design element on most surfaces and with the light reflected from the mouldings linking these); on the wooden minbar of the Alaeddin Mosque in Ankara of 1178; as on the minbar of the Divriği Külliyesi congregational mosque of 1228-9, as later on the wooden minbar of the Beyşehir Eşrefoğlu mosque of 1297-9) and in the mihrābs (Eg. as on the wooden mihrāb of the 1137 Kutubiye Mosque, Morocco, on the wooden mihrāb of Sayyida Nafisa of 1145-6, Cairo; on the wooden mihrāb of the maqam of Ibrahim of 1168 in the citadel of Aleppo; as later on the mihrāb surround of the Kayseri-Külük Mosque, in the carved stone taçkapı mihrāb-like niches of the Çifte Minareli Medrese, Erzurum of the late XIII ${ }^{\text {th }}$ c., and in the tile-work of the mihrāb of the Beyşehir Eşrefoğlu mosque of 1297-9) of some mosques; as also on wooden shutters over windows, as in muqarnas, (As in the upper sunburst form of the muqarnas employed as the ceiling of the shrine of the Imām at Dur in Iraq of 1085 and likewise in the upper sunburst form of the muqarnas employed to form the ceiling in the mausoleum of Nūr al-Din in the Madrasa al Nūriyya, Damascus of 1168) as on cenotaphs; (Eg. on the 1178 the wooden cenotaph of the Imam al-Shäfi, Cairo; as in cut-tile mosaic on XIII ${ }^{\text {th }}$ c. cenotaphs such as that of Kaykavas in Sivas and those in the former Mevlevi Teke, Konya) as likewise in the design in the frames on the carved stone portals of mosques, medrese (Figs. 7 \& 8), palace (Eg. 
On the doorway of the Ayyubid Palace on the citadel of Aleppo c. 1210), han and caravanserai, in Bagdad, Ayyubid Syria and subsequently in Seljuk Anatolia (Fig.9) (Eg. On the stone portal of the Divriği Külliyesi Şifahâne 1228-9, of the Sırçalı Medrese, Konya of 1242; on the portal of the 1231-6 Sultanhan on the Kayseri-Sivas road), on metalwork (Eg. Melikian-Chirvani, 1994, Figs. 150, 153), in cut-tile mosaic work (Fig. 10) (Eg. in the cut-tile work of the mihrab of the Ulu Mosque, Akşehir 1220-30; in the design of the cut-tile mosaic in the iwan of the Sirçalı Medrese, Konya of 1242, in the cut-tile work of the dome of the Karatay Medrese, Konya of 1251; in cut-tile work around the mihrab of the Sahip Ata Mosque, Konya of 1258, and in the mihrab of the Beyşehir Eşrefoğlu mosque of 1297-9), in the form of 8 pointed sunburst-'star' tiles (For numerous examples of 8 pointed 'star' tiles from the Alaaddin Köşkü, Konya and from Kubadabad, Beyşehir see, Arık 2000. For the matter of shamsa, rather than najmah, see above), on the main doors of buildings (Figs. 11 \& 12) (Eg. on the c. 1150 door of the bimaristan alNūrī in Aleppo, on the 1154 bimaristan al-Nūri in Damascus, on the 1219 double doors of the maqam of Ibrahim in the citadel of Aleppo, on the Diyarbakir Palace doors designed by AlJaziri by 1206 and on the Cizre Mosque doors, as above the lintel of the 1220 main portal of the

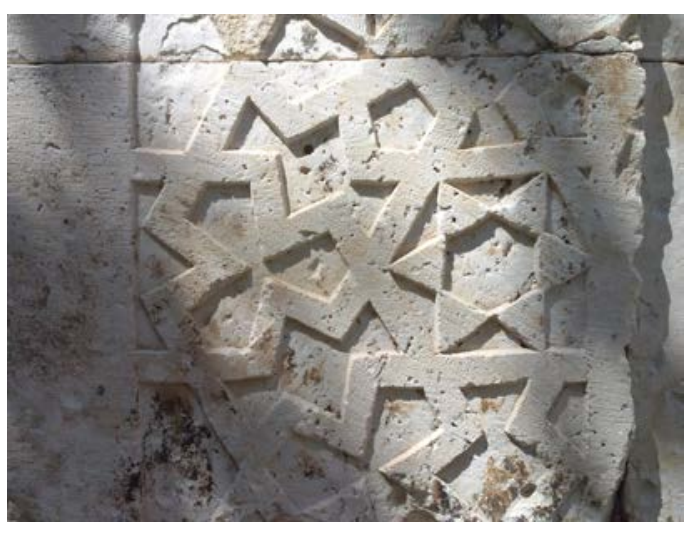

Fig. 7. Antalya Ulu Camii Medrese, detail of 6 pointed star within hexagon (Photo. Y. Doğan)

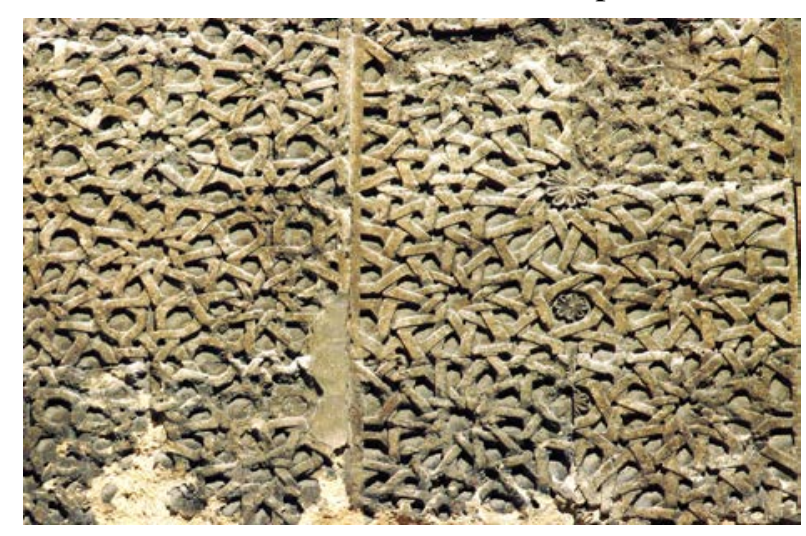

Fig. 8. Sırçalı Medrese portal (from S. Ögel, 1994, 99)

Alaeddin Mosque Konya, and the 5 pointed sunbursts-'stars' carved in the panel above the door on the Şifahane at Divriği.), like the star-like - sunburst motif struck on XII ${ }^{\text {th }}$ c. Ayyubid coinage (Eg. Balog, 1958, 303, 423, 586; YK 14246 (of 1185-6), 14301 (1193-4), 14311 (1204)), including on the dirhams of Salāh ad-Dīn Yusuf (As also on coins struck by the Artuqid Husam al-Din Yuluq Arslan in 1185, under the Ayyubid, Salāh ad-Dīn, YKB Inv. No. 15979), then in the XIII ${ }^{\text {th }}$ c. on the coinage of El-Evhad Nejmed-Din at Mayyafariqin in 1208-9 (YKB Col. Inv. No. 14636), by Nasir al-Din Mahmud 1220-21 in Diyarbakir (Turks Cat. No. 82) and at Aleppo by Sultan Giyathsed-Din Keyhusrev II in 1239-40 and 1241-2 on dirham (YKB Col. Inv. No. 8987, 8988), which were in all probability, all designed and were deliberately employed to bring to mind, that wonder that the sun-rosette-moon-star within and forming the shabaka the net, the lattice-kafes of this design can be understood to represent, "Each one has a "known station" and a specific degree which it does not overstep" (Al Ghazali, 1998, 14), like the more than 6,000 sunburst-rosettes between individual ayet of varying length on the pages of the Koran, and to thereby recall to the viewer both the Veil of Light and the mushaf; as also of the worlds within worlds illuminated by this Divine Light and, excepting for the 'Face' of the Almighty, al-azal, of the ultimate unreality of all that is, has been, and will be brought into existence.

It seems for example probable that a representation of the Veil of Lights, of ayet and 
shamsa, was what the designer intended to express through the blue background, repeat pattern of white lattice of pseudo text and red 8 pointed sunbursts-'stars' in the design on the field of the Seljuk carpets TIEEM, İst. Inv. No. 685 (Fig. 13); on the Mevlana Museum Inv. No. 867, fragment, carrying this same design but with a red field and blue-black lattice of pseudo text (Fig. 14); and also the design on a Seljuk carpet fragment from Beyşehir which can be understood as a reworking of this theme of Veil of Lights, of ayet and shamsa, Word and Light, consisting of 8 pointed sunbursts-'stars' in dark blue, white and red within a dark blue lattice on a paler blue field (Fig. 15) (Aslanapa 1988, Plate 12). The same it can be suggested is the meaning conveyed by the field with sunburst designs employed on the so-called, 'Holbein' and in the 'Star' Uşak carpets based upon an 8 pointed sunburst, etc.('The basic Star Uşak motif is always comprised of 8 pointed stars of two different types, developing from an essentially square-shaped centre'.

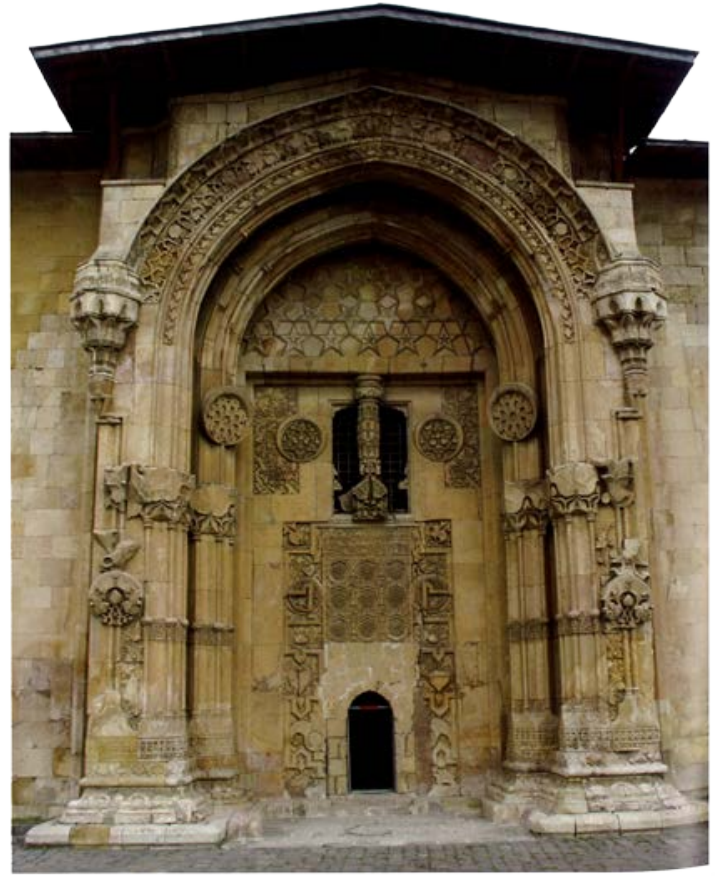

Fig. 9. Sunbursts-stars on the portal of the Divriği Külliyesi Şifahâne 1228-9 (from S. Ögel, 2006, 482)

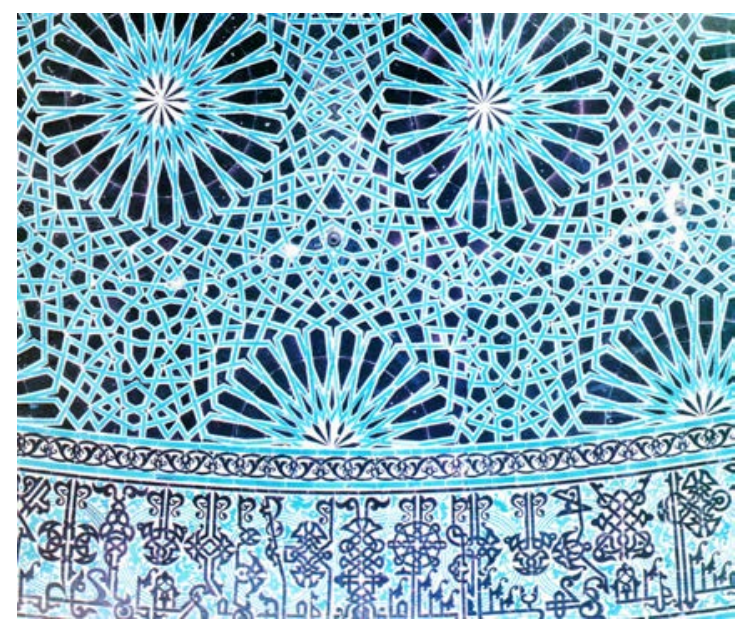

Fig. 10. Karatay medrese dome tile-work 1251 (from Firat, 1996)

Spuhler 2012, 45. As likewise on later Mamluke carpets and those copies thereof, eg. Aslanapa 1988, 141-2, Pl. 113). As perhaps is likewise the case with the increasing employment of a variety of light reflecting substances, of light reflecting textiles such as bukalemun (Serjeant, 1972, 142), works of lustre as noted above, and glass-like glazes on ceramics (For further on this see for example, Schnyder, 1994, 165-169), glass (Abu Hamid al-Ghazāli specifically refers to glass due to its refined translucent nature, "as (being) the first similitude of the imaginal spirit."- that is, within the hierarchy of spirits, after/above the sensory spirit, but before-below the reflective and then the rational spirit, because, "We find these three characteristics in relation to the seen lights of the visible world only in glass. Originally, glass is a dense substance, but once it is purified and made clear, it does not veil the light of the lamp. Rather, it conveys the light in a proper manner. Furthermore, it protects the light from being extinguished by violent winds and rough movements”, Al-Ghazali, 1998, 39-40) -plain, gilded and enamelled, glass lamp holders/mosque lamps, the use of light reflecting letters of gold or gold leaf, silver or 
silver leaf, in manuscripts, in inlays, as on building inscriptions, and of mirrors and mirror glass, as also the sun-burst-şemse-rosette and other related sun-'star' patterns on engraved and inlaid candlesticks (Melikian-Chirvani, 1994, and particularly 150 and fn. 47 \& 48, in reference to Rumi's the dancing sun in the sky and a hundred sun and wheels (chark=wheel, sky), of skies filled with suns); as likewise with the pools/basins of mercury and those of water lined with tin, as on light reflecting-absorbing textiles (see above), as all these are materials and designs that served and serve today as a reminder, within this context of the temporal world, of Light, of the Veil of Light and of the consequent worlds of phenomena.

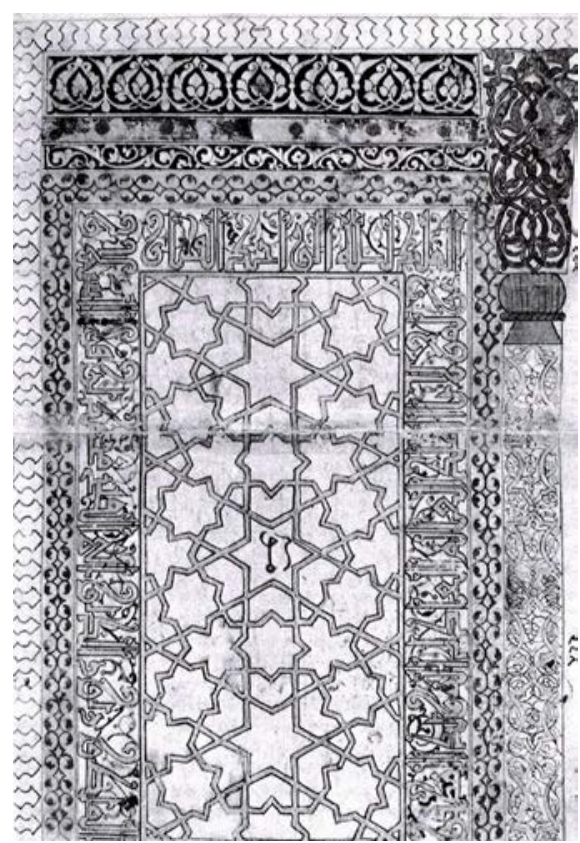

Fig. 11. The 1206 design of the Diyarbakır Palace Door (Tabbaa, 2001, Fig 46)

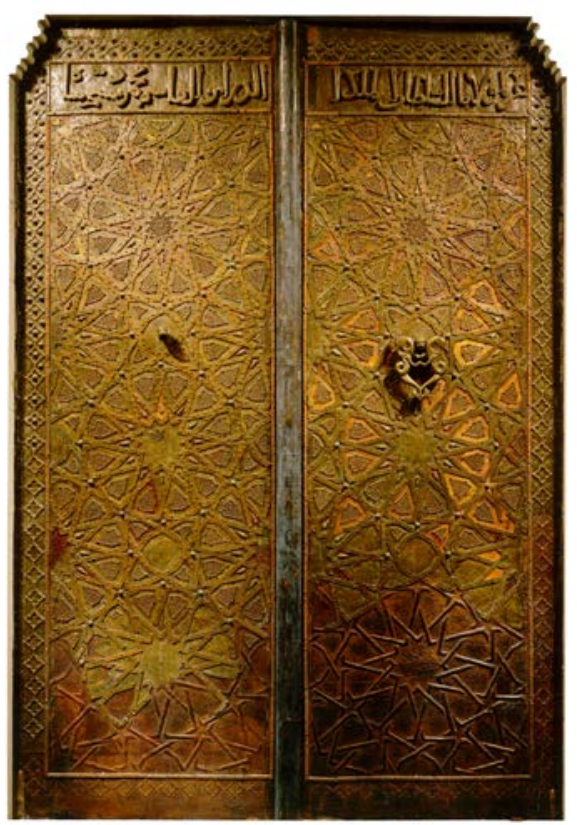

Fig. 12. Cizre congregational mosque doors (from Ülçer, 2005, Fig. 87)

Consequently, it seems that rather than O. Graber's characterisation of geometric ornament as, "an abstraction that seems devoid of cultural specificity. It is only meant to be beautiful." (Graber 1992, 154), it was perhaps more the case that, as well as meaning to be beautiful, it was also the case that for the sunbursts-rosettes-'stars' within and ordering a shabaka net pattern, a geometric pattern, with at times the geometric pattern itself designed to suggest the letters of script as is noted above (Figs. 13 \& 14), that these designs carried in their initial use from the $\mathrm{XI}^{\text {th }}$ to the $\mathrm{XIV}^{\text {th }}$ centuries a religious meaning of some quite considerable significance, which was expressed over the material surface of a range of cultural-religious artefacts. One may see in these designs not only a metaphorical representation of the ayet and shamsa, that is, indications-reminders of the Word and of the Light, but also the articulation of that which is recorded by Abu Hamid al-Ghazāli (1058-1111) in his Miskhāt al-Anwār (The Niche of Lights):

"There are in the world of dominion noble and high luminous substances called "angels." Lights effuse from these angels upon human spirits, and because of these lights these angels may be called "lords" - that is why God is "Lord of the lords" (In reference to the Holy Koran: "Imran 3:80, "And he commanded you not that ye should take the angels and the prophets for lords. Would he command you to disbelieve after ye had surrendered (to Allah)?” Al Ghazali clearly distinguishes these lights- 
illuminated angels from being the object of worship). These angels have diverse levels in their luminosity. Hence, it is appropriate for their similitude in the visible world to be the sun, the moon and the stars" (Al Ghazali, 1998, 27. One may be reminded for example of the roundels, the upper borders of which, when seen from below, form crescent moons, while in the roundels are 8-pointed sunbursts-stars on the portal of the Divriği Külliyesi Şifahâne of 1228-9).

"These four lights are ranked in levels such that some are higher and more perfect than others. Each one has a "known station" and a specific degree which it does not overstep" (Al Ghazali, 1998, 14).

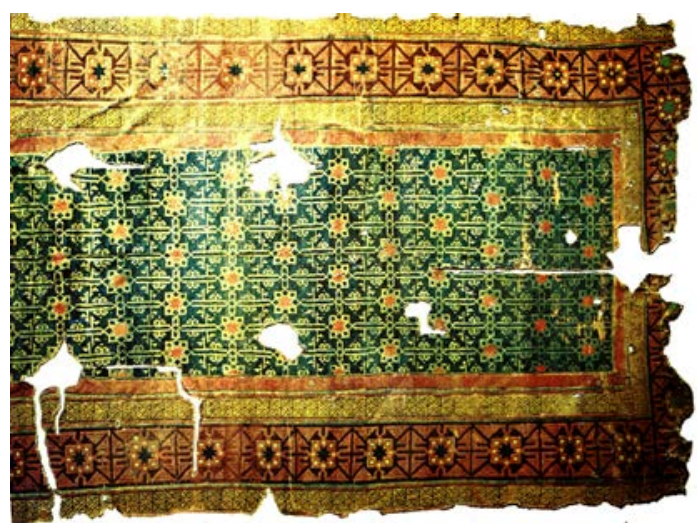

Fig. 13. Seljuk carpet TİEM, İst. Inv. No. 685 (from Aslanapa, 1988, 19, Pl. 5)

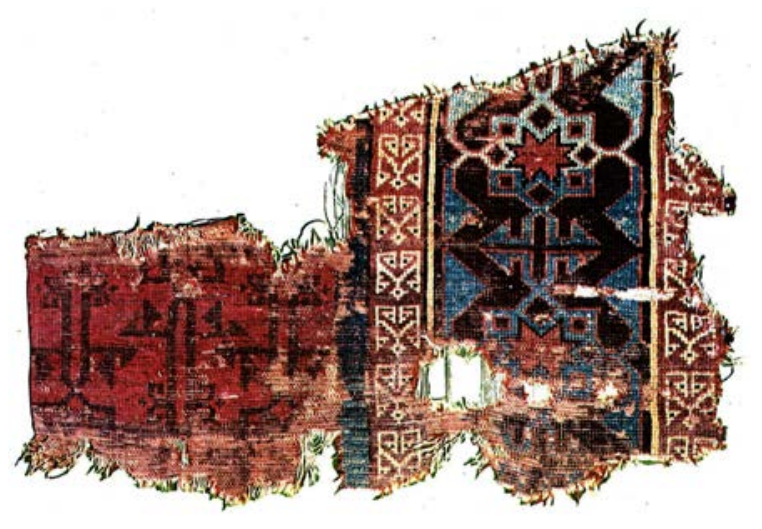

Fig. 14. Seljuk carpet fragment, Mevlana Museum, Konya, Inv. No. 867 (from Aslanapa, 1988, 25, Pl. 11)

An explicit depiction of this metaphysical understanding of Light is provided by the depiction of the 'Sun' with the 'full-moon face' struck within it, circulated on the coinage of Sultan Giyathsed-Din Keyhusrev II (1236-47) (Fig. 16), that can be understood as representing through this 'Face' in the moon visible within the Veil of the Sun, the Light of the Almighty's Love, as reflected in the love of Belkis and Suleyman, as of Shirin and Khusrev (Duggan, \& Belkis, 2011, particularly 171-2), and likewise, as earlier (As for example on the lustre tile depicting the face in the sun within an 8-pointed sunburst-star tile from the Palace of Kubadabad by Lake Beyşehir, probably from before 1237, Arik, 2000, Fig. 175), (Fig. 17) serving as an explicit reminder, an indication of the Light of the Sun and the reflection of sunlight in the moonlight of the full moon, which are combined together within this image (One maybe reminded of the importance of the sun and the moon from the hadith narrated Abu Masud: Allah's Apostle said, "The sun and the moon do not eclipse because of someone's death or life but they are two signs amongst the signs of Allah, so pray whenever you see them.", and that narrated Abu Bakra: "We were with Allah's Apostle when the sun eclipsed. Allah's Apostle stood up dragging his cloak till he entered the Mosque. He led us in a two-Rakat prayer till the sun (eclipse) had cleared. Then the Prophet said, "The sun and the moon do not eclipse because of someone's death. So whenever you see these eclipses pray and invoke (Allah) till the eclipse is over", Sahih Bukhari 18, 165 and 150 respectively), as in the parallel drawn by Abu Hamid al-Ghazāli in his commentary on the Divine Name Al-Nūr (above), that is, being a clear representation and a reminder of the, "Light upon Light.", revealed to the believer through the Sura Al-Nür, (Chapter The Light) 24:35.

An example of the related concern, with the properties of light itself, associated with the 
Caliph as temporal ruler, the Shade-Shadow of the Almighty (In another sense, "The shadow of God is that servant of God who is dead to this world and living through God.", Rumi, 1982, 423), (hence the ruler's parasol), is recorded in the account given of the appearance of the Hall of the Caliphs in c. 950 in the Palace of az-Zahra, by Cordoba during the reign of the Omayyad Caliph ‘Abd al-Rahman III:

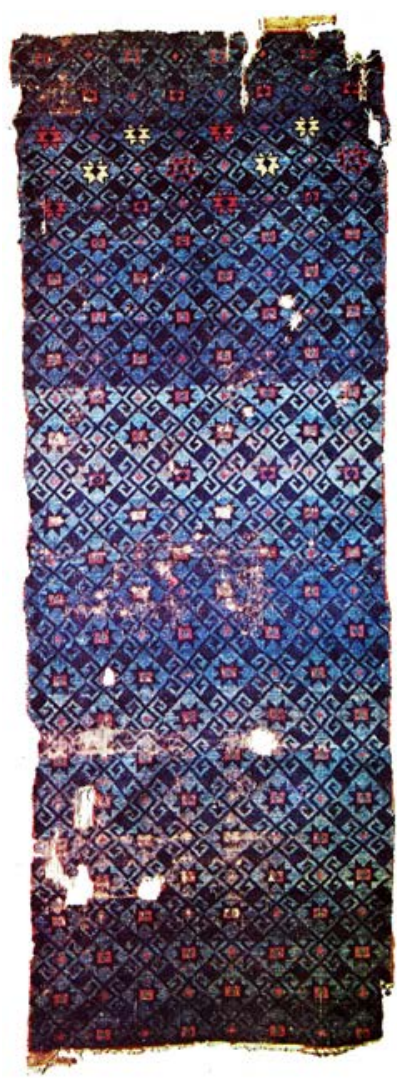

Fig. 15. Beyșehir sunburst carpet from (Aslanapa, 1988, 23, Pl. 12)

"Another of the wonders of az-Zahra was the Hall of the Caliphs, the roof of which was of gold and solid but transparent blocks of marble of various colours, the walls being likewise of the same material...There was in the centre of the room a large basin filled with quicksilver, on each side of it eight doors fixed on arches of ivory and ebony, ornamented with gold and precious stones of various kinds, resting upon pillars of variegated marble and transparent crystal. When the sun penetrated through these doors into the hall, so strong was the action of its rays upon the roof and walls that the reflections only were sufficient to deprive the beholders of sight. And when the caliph wished to frighten any of the courtiers that sat with him, he had only to make a sign to one of his slaves to set the quicksilver in motion, and the whole room would look in an instant as if it were traversed by flashes of lightning and the company would begin to tremble, thinking that the room was moving away" (Fletcher, 1989, 22-23, citing from al-Maqqari's History of al-Andalus).

Although the deployment of the above mentioned types of sun, shamsa-'little suns'-stars defining and focussing and centring geometric patterns was a feature of the hijab-the veil of surfacing applied during the $\mathrm{XI}^{\text {th }}$ to $\mathrm{XIII}^{\text {th }}$ centuries, as subsequently particularly under the Mamlukes, rather than of the $X^{\text {th }}$ c., the attempt to embody this understanding, a consequence of a deep and longstanding Islamic concern with the symbolism of light and its reflections - with the Veil of Light(s), as in the production and import of fine glazed ceramics, the development of luster painted on glass (For examples see, Carboni, 2001, 51-69) and then lustre paintwork on potterylusterware (See for example, the $\mathrm{IX}^{\text {th }}$ c. Abbasid, the Fatimid and the Seljuk lusterwares: Watson, 2004, Abbasid lusterware 182-197, Fatimid lustre pottery 273-287; Seljuk lusterware 347-361; Mason, 2004 passim), and an emphasis upon the light reflecting qualities of materials in the manufacture of physical objects, of course existed in the $\mathrm{X}^{\text {th }}$ c. as earlier (It is somewhat unfortunate to find that the longstanding Muslim concern with the light and the Veil of Light has recently been most considerably circumscribed, reduced and limited in XIII ${ }^{\text {th }}$ c. Seljuk territory to the influence of Suhrawardī Maqtul and the ishrāqı school of illumination. The 
concern with the Veil of Light and its articulation and representation in design begins considerably earlier and therefore cannot be tied either in its inception, nor limited in its spread to this $\mathrm{XII}^{\text {th }} \mathrm{c}$. somewhat controversial figure, contra the suggestion made by S. Yalman “...his (Shihāb ud-Dīn asSuhrawardī c. 1170-1191) Illuminationist teaching seems to be echoed in the light symbolism that continued to flourish under Anatolian Seljuq sultans such as Kayqubad." Yalman, 2012, 153. The use of designs of this nature, of light and of the 'sun' occurred repeatedly in Syria under Sultan Nūr alDīn (r.1147-74) and even earlier in surviving $\mathrm{XI}^{\text {th }} \mathrm{c}$. manuscript illuminations, before they occur in Rum Seljuk territory and this understanding of the importance of Light and of the Veil of Light was both expressed and given widespread currency through works produced nearly a century earlier than Suhrawardī Maqtul, by both Abu Hamid alGhazāli, Hujjatu 'L-Islam (1058-1111) and his brother Ahmad al-Ghazāli (d. 1126) in works including those cited from above, as also through the repeated use of decoration that can be understood as representing this from the $\mathrm{XI}^{\text {th }}$ c. onwards in the mode of shabaka geometric designs with sunrosette-star designs. This perspective embraced a far wider prospect and began more than a century earlier, outside of elements of Zoroastrian religious thought, such as, "The Zoroastrian fire, Suhrawardī argues, is the divine light and farwahar as archetype of the human souls which descends upon the human body after it is conceived" Razavi, 1997, 83, and likewise is distant from Zoroastrian angelology. Suhrawardī's suggested influence contributing to the use of these designs in Anatolia seems to be unsupported, while the contacts with ibn Arabi at state level are documented, and trained Syrian designers-architects such as: Abu Ali ar-Rakka alKattani al Halabi (of Aleppo) who was working in Sinope by 1216, or Muhammed b. Havlân alDimaşkî, all three of whom would have been familiar with examples of this pattern from the buildings of Nürid Syria seem to have been the more probable continuators of this repertory of designs and to have been influential in its spread in XIII ${ }^{\text {th }} \mathrm{c}$. Seljuk territory, rather than the influence of the illuminationist teachings of Suhrawardī Maqtul), in

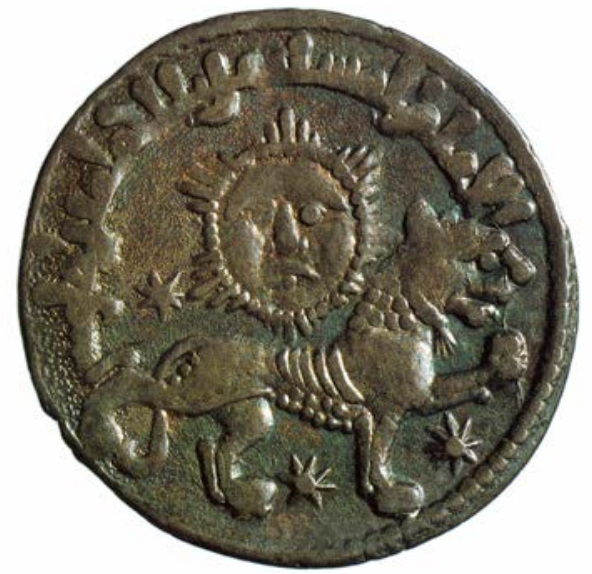

Fig. 16. Dirham of Sultan Giyathsed-Din Keyhusrev (1236-47) representing the 'face of the moon' within the Veil of the Sun, Light.

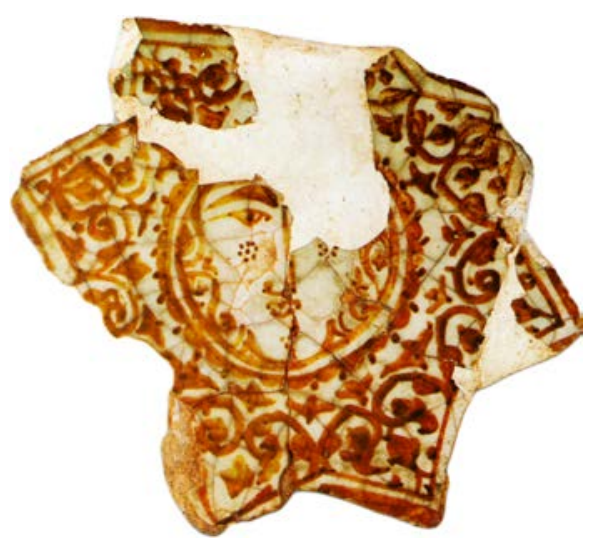

Fig. 17. Lustre painted tile, Light upon Light, from the Kubad abad Palace Beyşehir c. 1236 (from Arık, 2000)

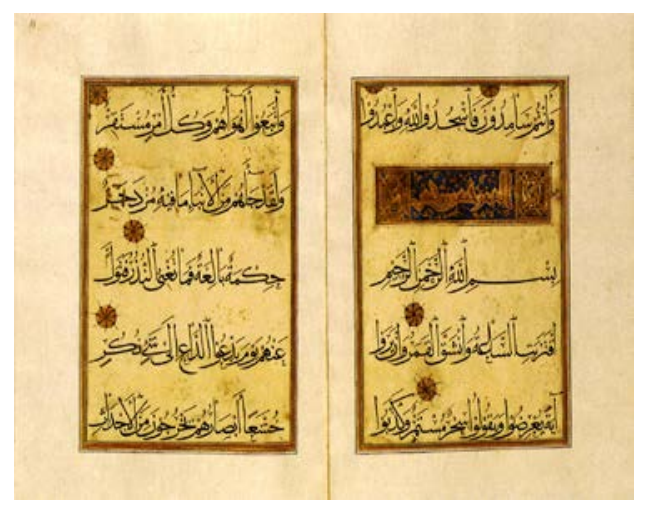

Fig. 18. Late XIII ${ }^{\text {th }}$ c. Koran Section written by Yaqut al-Musta'simi with shamsa (from Pancaroğlu, 2005, 96, Fig. 53) 
environments both Sunni and Shii'ite (As for example the panegyrist of the Fatimid Caliph AlMuizz, Ibn Hāni' al-Andalusī, Abu'l-Qasim Muhammad b. Hāni' b. Muhammad b. Sa'dūn alAzdi d. c. 973, who described in his poetry the shamsa, the ceremonial Parasol which the Imam has carried above him during his procession in Al-Qahira and the Godly light of the Fatimid Imam, as likewise the early pre-Fatimid Isma'ili emphasis on creation out of light and the veiling of the Creator, eg. Halm, 2001, 76-79; as also Daftary, 2007, 134-136), and this focus found its initial expression, and one which continues today to serve as a continual reminder of the Veil of Light(s), in the şemse-shamsa-rosettes, sunburst markers of intervals, of gold, of light, together with those other reminders of The Light within the calligraphic text of the pages of the Holy Koran (Fig. 18).

\section{LIST OF ILLUSTRATIONS}

1. Koran page (from Blair, 2006, Fig. 4.4)

2. Blue Koran page (from Burckhardt, 1976, Pl. 23)

3. $\mathrm{XI}^{\text {th }}-\mathrm{XII}^{\text {th }}$ c. Koran Section with shamsa (from Pancaroğlu, 2005, 82, Fig 36)

4. Koran frontispiece 1036, (from Tabbaa, 2001, 49)

5. Nur ed-Din minber 1168-74, sunbursts and 'stars' on the side of the al-Aqsa minbar (from Singer, 2008, 70)

6. Eşrefoğlu minber 1297-9, detail of sunburst on minbar (from Fırat, 1996)

7. Antalya Ulu Camii Medrese

8. Surçalı Medrese portal (from S. Ögel, 1994, 98)

9. Sunbursts-stars on the portal of the Divriği Külliyesi Şifahâne 1228-9 (from S. Ögel, 1994, 99)

10. Karatay medrese dome tile-work 1251 (from Firat, 1996)

11. The 1206 design of the Diyarbakir Palace Door (Tabbaa, 2001, Fig 46)

12. Cizre congregational mosque doors (from Ülçer, 2005, Fig. 87)

13. Seljuk carpet TİEM, İst. Inv. No. 685 (from Aslanapa, 1988, 19)

14. Seljuk carpet fragment, Mevlana Museum, Konya, Inv. No. 867 (from Aslanapa, 1988, 25)

15. Beyşehir sunburst carpet from (Aslanapa, 1988, 23)

16. Dirham of Sultan Giyathsed-Din Keyhusrev (1236-47) representing the 'face of the moon' within the Veil of the Sun, Light upon Light (from Schöttler, 1995, Fig 459)

17. Lustre painted tile from the Kubad abad Palace Beyşehir c. 1236 (from Arık, 2000)

18. Late XIII ${ }^{\text {th }}$ c. Koran Section written by Yaqut al-Musta'simi with shamsa (from Pancaroğlu, 2005, 96, Fig. 53)

\section{REFERENCES}

Addas, C. (1993). Quest for the Red Sulphur, The Life of Ibn 'Arabı. The Islamic Texts Society, Cambridge.

Addas, C. (2000). Ibn 'Arabi, The Voyage Of No Return. The Islamic Texts Society, Cambridge.

Aminrazavi, M. (2007). The Wine of Wisdom, The Life, Poetry and Philosophy of Omar Khayyam. Oneworld, Oxford.

‘Arabi (2000). L. Shamash. “The People of the Night”. Foundations of the Spiritual Life according to Ibn 'Arabi-Prayer and Contemplation, 42-53. Ed. S. Hirtenstein, Muhyiddin Ibn 'Arabi Society, Oxford.

'Arabi (1989). Ibn al-'Arabi, Risalat al-anwar, Journey to the Lord of Power-A Sufi Manual on Retreat, Trans. R. T. Harris. Inner Traditions International, Rochester, Vermont.

Arberry, A. J. (1969). Poems, An Anthology of Verse Translations. Everyman's Library No. 996, Dent, 
London.

Arık, R. (2000). Kubad Abad. İstanbul: Türkiye İş Bankası Yayınları.

Arnold, Sir T., W. (1965). Painting in Islam, A Study of the Place of Pictorial Art in Muslim Culture. Constable, London.

Aslanapa, O. (1988). One Thousand Years of Turkish Carpets. İstanbul: Eren Yayınları.

Attar (1978). Attar, The Conference of the Birds by Farid ud-Din Attar, A translation of the Persian Poem Mantiq ut-Tair rendered into English by C. S. Nott, Samuel Weiser, New York, (1954).

Balog, P., \& Yvon, J. (1958). “Monnaies à légendes arabes de l'Orient latin”. Revue numismatique, Vol. 6, No. 1 133-168.

Bierman, I., A. (1998). Writing Signs, The Fatimid Public Text. Berkley/Los Angeles/London: University of California Press.

Blair, S. (2006). Islamic Calligraphy. Edinburgh: Edinburgh University Press.

Bloom, J. M. (2013). “The Minaret”. Edinburgh Studies in Islamic Art. Edinburgh: Edinburgh University Press.

Burckhardt, T. (1989). Mystical Astrology According to Ibn 'Arabi. Trans. B. Rauf. Abingdon: Beshara Publications.

Burckhardt, T. (1976). Art of Islam, Language and Meaning. London: World of Islam Festival Publishing Company.

Cameron, L., \& Jackson, D., E., P. (1997). Saladın, The Politics of the Holy War. Cambridge: Cambridge University Press.

Carboni, S. (2001). Glass from Islamic Lands, Kuwait National Museum. The Al-Sabah Collection, London: Thames and Hudson,.

Chittick, W. C. (1983). The Sufi Path of Love, The Spiritual Teachings of Rumi. Albany: State University New York.

Coomaraswamy, A., K. (2004). The Essential Ananda K. Coomaraswamy. World Wisdom Inc., 2004.

Daftary, F. (2007). The Ismā '̄ilìs, Their History and Doctrine. Cambridge: Cambridge University Press.

Duggan, T. M. P. (2013). Review of, J. M. Bloom, The Minaret. Edinburgh Studies in Islamic Art, Edinburgh. MJH, 2013, 3/2, 357-365.

Duggan, T. M. P. (2011). "The temporal world - a shadow play-court and urban shadow plays of the $11^{\text {th }}$ to $14^{\text {th }}$ centuries". MJH, 2011, 1/1, 83-92.

Duggan, T. M. P. (2011). “An interpretation of some unpublished in situ and recorded Rum Seljuk 13th c. external and internal figural relief work on the Belkis (Aspendos) Palace, Antalya”. Gephyra, 8, 143-184, 2011.

Duggan, T. M. P. (2006). "The Motifs Employed on Rum Seljuk $13^{\text {th }}$ Century Eight Pointed Star Tiles from Antalya Province and Elsewhere in Anatolia: An Interpretation”. ADALYA, IX, 149-219.

Feinberg, C. L. (1958). “The Scapegoat of Liviticus” Bibliotheca Sacra 115, 16, 320-33. Dallas Theological Seminary, Dallas, Texas.

Fitzgerald, E. (1970). The Rubaiyat of Omar Khayyam. Folio Society, London, (1859).

Fırat, S. (1996). Selçuklu Sanatı, The Art of the Seljuks. Ankara: T.C. Kültür Bakanlığı Yayınları.

Fletcher, R. (1989). The Quest for El Cid. London: Hutchinson.

Ghazzalī, A. (1986). Sawānih Inspirations from the World of Pure Spirits, The Oldest Persian Sufi Treatise on Love. Trans. N. Pourjavady. London: KPI.

Al Ghazali (1998). The Niche of Lights. Trans. D. Buchman. Utah: Brigham Young University Press.

Al Ghazali (1992). Al Ghazali on the 99 Names of God, al-Maqsad al-asnā fi sharh asmā' Allah alhusnā. Trans. with Notes by Burrell, D., B., \& Daher, N. Cambridge: The Islamic Texts Society.

Graber, O. (1992). The Mediation of Ornament. New Jersey-Princeton: Princeton University Press.

Halm, H. (2001). “The Cosmology of the Pre-Fatimid Ismā'îliyya”. 75-89. Ed. F. Daftary, Medieval Isma'ili History and Thought. Cambridge: Cambridge University Press.

Jackson, W. J. (2004). Heaven's Fractal Net: Retrieving Lost Visions in the Humanities, Vol. 1. Indiana 
University Press.

Ibn Qayyim al-Jawziyya (2004). Ibn Qayyim al-Jawziyya, The Invocation of God, Al-Wābil al-Sayyib min al-Kalim al-Tayyib, Trans. M. A. Fitzgerald, \& M. Y. Slitine Cambridge: Islamic Texts Society.

Mason, R. B. (2004). Shine Like the Sun: Lustre-Painted and Associated Pottery from the Medieval Middle East. California: Mazda Pub, Costa Mesa.

Masudi (1989). The Meadows of Gold-The Abbasids. Trans \& Eds. Lunde, P., \& Stone, C. Keegan Paul Int., London \& New York.

Melikian-Chirvani, A., S. (1994). “The Light of the World”. The Art of the Saljuks in Iran and Anatolia, 146-153. Ed. R. Hillenbrand. Mazda, Costa Mesa, California.

Nasr, S. H. (1963). Three Muslim Sages. Cambridge, Mass.

Nicholson (1914). Ali al-Sarraj al-Tusi, Kitab al-luma' fi al-tasawwuf. Translated and Ed. Nicolson, R., A. London and Leiden, Luzac \& Co., Brill.

Nizami (1924). Nizami of Ganja, \& C. E. Wilson. Haft Paikar (The Seven Beauties), Vol. 1. London Arthur: Probsthain.

Ögel, S. (1994). Anadolu’nun Selçuklu Çehresi. İstanbul: Akbank Yayınları.

Pancaroğlu, O. (2005). “The emergence of Turkic Dynastic Presence in the Islamic World”. Ed. D. J. Roxburgh, Turks, a Journey of A Thousand Years, 600-1600, 72-101. Royal Academy of Arts, London.

Peters, F. E. (1994). The Hajj: The Muslim Pilgrimage to Mecca and the Holy Places. Princeton: Princeton University Press.

Razavi, M. A. (1997). Razavi, Suhrawardi and the School of Illumination. Curzon, Richmond.

Rumi (1982). The Mathnawi of Jalalud'din Rumi. Trans. R. A. Nicholson. Books I-VI, Gibb Memorial Trust, Cambridge.

Rumi (1977). Rumi, Selected Poems from the Dīwāni Shamsi Tabrīz. Ed. R. A. Nicholson. Cambridge: Cambridge University Press,.

Serjeant, R. B. (1972). Islamic Textiles: Material for a History up to the Mongol Conquest. Beirut: Libraire du Liban.

Schimmel, A. (1978). Mystical Dimensions of Islam. The University of North Carolina Press, Chapel Hill.

Schimmel A. (2001). As Through a Veil, Mystical Poetry in Islam. Oxford, Oneworld.

Schnyder, R. (1994). "In Search of the Substance of Light”. The Art of the Saljuks in Iran and Anatolia, 165-169. Ed. R. Hillenbrand. Mazda, Costa Mesa, California.

Schöttler, P. (1995). “Die Rumseldschuken Gründe Der Türkei”. Geschichte und Kultur. Schillinger Verlag, Freiburg im Breisgau.

Shah, I. (2000). The Perfumed Scorpion. London: Octagon Books.

Shakoor, M. (2012). Corridor of Shadows. İstanbul: Timas Publishing.

Singer, L. (2008). The minbar of Saladın- reconstructing a Jewel of Islamic Art. London: Thames \& Hudson.

Spuhler, F. (2012). Carpets From Islamic Lands, Dar al-Athar al-Islamiyyah. The Al-Sabah Collection, Kuwait, London: Thames \& Hudson.

Tabbaa, Y. (2001). The Transformation of Islamic Art during the Sunni Revival. University of Washington Press, Washington \& Seattle.

Ülçer, N. (2005). “The Anatolian Seljuks”. Ed. D. J. Roxburgh. Turks, A Journey of a Thousand Years, 600-1600, 104-145. London: Royal Academy of Arts.

Watson, O. (2004). Ceramics from Islamic Lands, Kuwait National Museum. The Al-Sabah Collection, London: Thames and Hudson.

Yalman, S. (2012). “Ala al-Din Kaykubat illuminated: A Rum Seljuq Sultan as Cosmic Ruler”. 151-186 in Muqarnas, 29, Brill. 
